\title{
Analyst
}

raculomene



ISSN 0003-2654

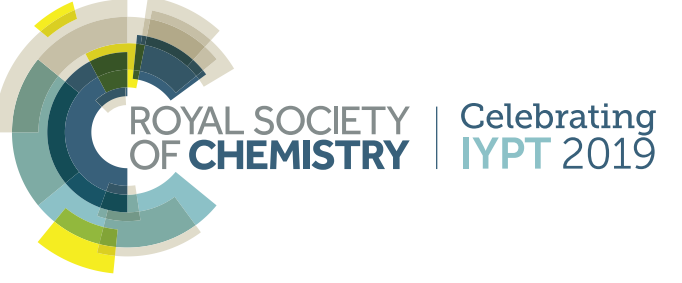

\section{CRITICAL REVIEW}

Jorge A. M. Pereira et al.

Current trends on microextraction by packed sorbent -

fundamentals, application fields, innovative improvements

and future applications

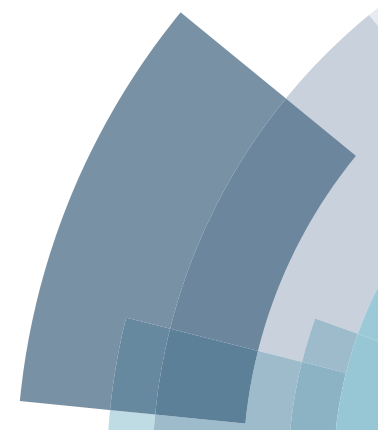




\section{Analyst}

A) Check for updates

Cite this: Analyst, 2019, 144, 5048

\section{Current trends on microextraction by packed sorbent - fundamentals, application fields, innovative improvements and future applications}

\author{
Jorge A. M. Pereira, (iD *a João Gonçalves, (iD a Priscilla Porto-Figueira, (iD a \\ José A. Figueira, (D) ${ }^{a}$ Vera Alves, (D) ${ }^{a}$ Rosa Perestrelo, (D) ${ }^{a}$ Sonia Medina (D) a and \\ José S. Câmara (D) a,b
}

Received 19th December 2018 Accepted 23rd June 2019

DOI: $10.1039 / c 8 a n 02464 b$ rsc.li/analyst

\begin{abstract}
MEPS, the acronym of microextraction by packed sorbent, is a simple, fast and user- and environmentally-friendly miniaturization of the popular solid-phase extraction technique (SPE). In fact, it has been widely shown that MEPS can easily replace SPE for most, if not all, previous applications. It can attain this with obvious gains in sample and solvent usage, which is greatly reduced without compromising the extraction efficiency. Furthermore, MEPS can be operated with semiautomatic electronic syringes, making it very reliable and versatile, particularly to handle very low and very high sample volumes. This review will focus on the strengths and weaknesses of this technique and the different MEPS architectures commercially available in the context of the MEPS applications reported in the last five years. Additionally, innovative improvements will be highlighted, particularly those related with new applications and recent MEPS configurations and sorbents, such as the controlled directional flow or the innovative $\mu$ SPEed variant.
\end{abstract}

\section{Introduction}

In recent years, extraction procedures in the microliter range with low reagent and sample volume requirements gained increasing relevance. The work of Abdel-Rehim (2004), ${ }^{1}$ describing the miniaturization of conventional solid phase extraction (SPE) in packed bed devices, particularly syringes, is usually described as one of the triggers for this trend. This format, MEPS (microextraction by packed sorbent), is essentially represented by the commercial presentation, in which a small amount of the sorbent, usually 1-4 $\mathrm{mg}$, is either inserted into the syringe barrel (BIN - barrel insert and needle) as a plug or between the needle and the barrel as a cartridge (Fig. 1). This format provides a selective medium suitable for sampling under a wide range of different conditions and target analytes. ${ }^{2}$ Furthermore, it can be easily interchanged between the manual mode using a Hamilton syringe, the semiautomatic version driven by the eVol® electronic syringe, or fully automatic autosamplers (Fig. 1). In contrast, many reports involving in-house devices similar to original $\mu$ SPE proposed by Abdel-Rehim $(2004)^{1}$ are essentially proof of concept devices designed to accommodate custom sorbents.

\footnotetext{
${ }^{a}$ CQM - Centro de Química da Madeira, Universidade da Madeira, Campus da Penteada, 9020-105 Funchal, Portugal. E-mail: jorge.pereira@staff.uma.pt

${ }^{b}$ Faculdade de Ciências Exatas e da Engenharia, Universidade da Madeira, Campus da Penteada, 9020-105 Funchal, Portugal
}

Regardless of the presentation format, in technical terms, a fundamental difference between MEPS and commercial SPE, is that the packing is integrated directly into the syringe and not in a separate column. So, MEPS can handle small sample volumes $(\sim 10 \mu \mathrm{L})$ as well as large volumes $(>1000 \mu \mathrm{L})$ without compromising the extraction efficiency. Beyond the obvious enrichment factor, this approach for sample preparation has several additional advantages, involving much lower solvent and sample requirements, easy and fast operation and a minimal cost of analysis, particularly when compared to conventional SPE. ${ }^{3}$ Previously, different reviews introduced MEPS and spanned its potential in microextraction as a more efficient and greener alternative to SPE and other forms of microextraction. ${ }^{1,2,4-8}$ Meanwhile, other studies focused on MEPS applications in particular topics, such as bioanalysis ${ }^{3,4,7,9}$ and medical diagnosis, ${ }^{10}$ and more recently, vlckova et al. (2016) explored specifically the development of MEPS-UHPLC-MS/MS methods for the clinical analysis of statins. ${ }^{11}$ In this review, we will critically assess the MEPS applications reported in the last five years in the context of the different MEPS architectures used. This will certainly contribute to unveil and broaden the range of applications for MEPS and particularly for its recent and innovative $\mu$ SPEed configuration.

\section{Technical considerations about the MEPS procedure}

MEPS is a microextraction approach tailored for liquid samples and so additional sample pre-treatment can be 


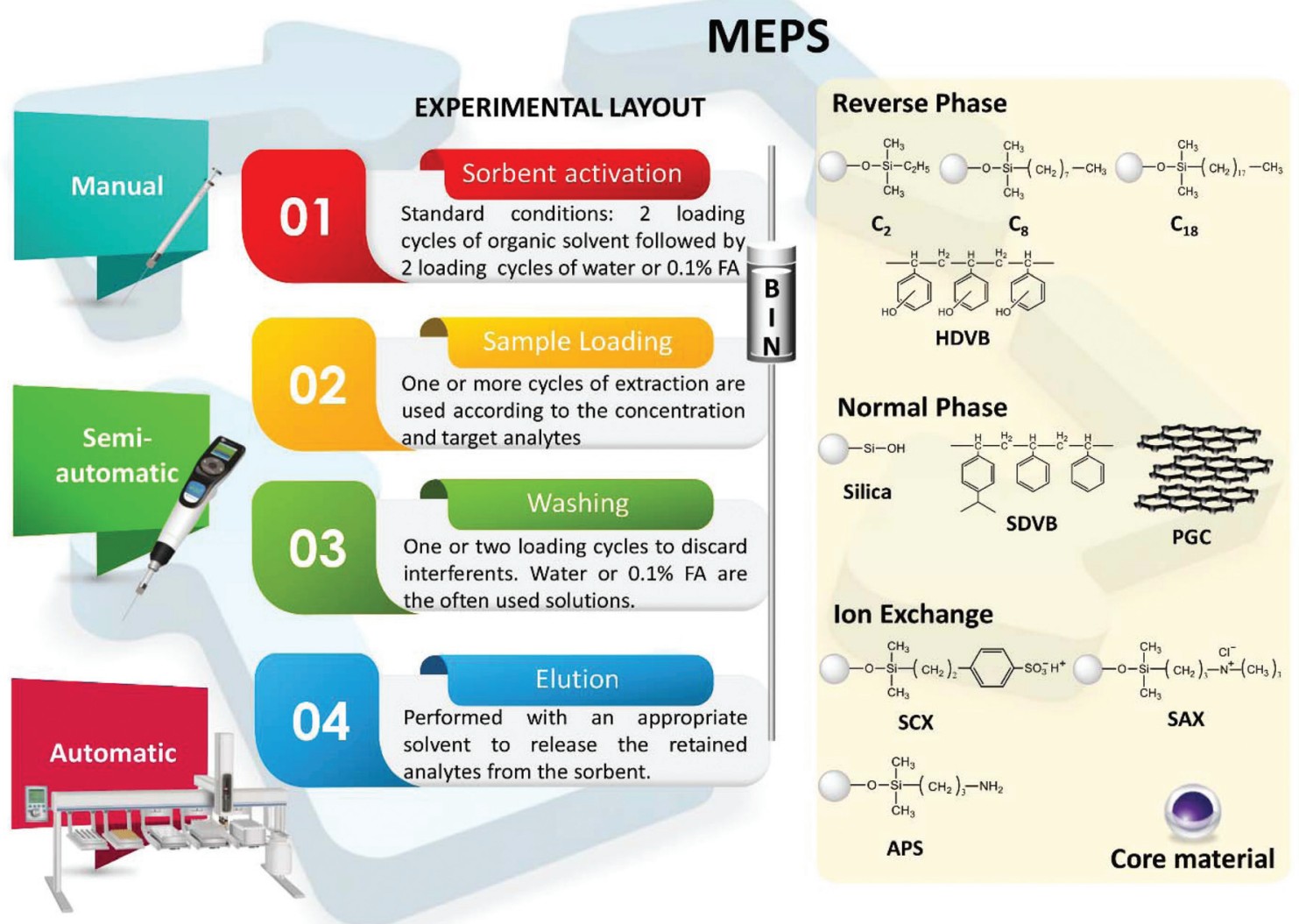

Fig. 1 Experimental layout of the MEPS procedures, highlighting the MEPS formats available (manual, semi-automatic and automatic), a short description of the different operation steps (activation, sample loading, washing and elution), and the main sorbents commercially available and chemistry involved in the interaction with target analytes (reverse and normal phase and ion exchange).

necessary under certain conditions. This is the case of solid samples, for which a dissolution or extraction with a broad solvent like $\mathrm{MeOH}$ can be particularly helpful to transfer the target analytes to the liquid phase before its processing with MEPS. But complex liquid matrices may also require pre-treatment procedures to avoid sorbent clogging and extend its reusability. Furthermore, this is also crucial to the extraction and concentration of low-abundance analytes, therefore ensuring high sensitivity and selectivity. Sample dilution to decrease the viscosity, precipitation and filtration with selective filters to remove matrix interferents are often reported for such cases. At a different level, $\mathrm{pH}$ adjustment may be required to modulate the interaction of the target analytes with the sorbent, particularly when using ionic exchange sorbents. Other generic sample pre-treatment procedures used previously to MEPS include sample homogenisation using vortex or ultrasound and centrifugation. In this context, the critical evaluation of sample pre-treatment techniques ${ }^{12}$ or the review devoted to the extraction of veterinary antibiotics from environmental waters may be particularly relevant for some readers. ${ }^{13}$ The MEPS procedure usually follows the conventional 4-step SPE: conditioning of the stationary phase, sample injection, washing and elution (Fig. 1). Despite this simplicity, MEPS involves a wide range of optimization steps that allow a fine tuning of the extraction efficiency. ${ }^{5}$ The appropriate selection of the sorbent, for instance, is of utmost importance to achieve satisfactory clean-up and analyte recovery. Moreover, depending on the target analytes, some steps can be simplified or skipped. The number of extraction cycles, for instance, can be increased by drawing the sample through the needle into the syringe several times (draw-eject), leading to a higher recovery level that can be optimized for each application. ${ }^{14}$ Upon the target analyte retention in the solid phase packed into the BIN, the washing step is usually considered to remove matrix interferents. This is an important part of the MEPS procedure since it is intended to discard unwanted and weakly retained interferents, eventually allowing a significant increase in the extraction efficiency. ${ }^{14}$ In most applications reported, this step is performed with the same solvent used to equilibrate the sorbent in the first step. ${ }^{5}$ However, this decision should be carefully considered and optimized. The increase of the organic solvent in the washing solution is required for an efficient removal of matrix interferents, but also favours the leakage of the target analytes from the sorbent (elution). The target analytes are eluted in the final step, which should also be critically optimized to allow the release of the analytes from the sorbent in a suitable solvent. Typically, this step is performed with an organic solvent, namely methanol (MeOH), 
isopropanol (IPA) or acetonitrile (ACN), pure or mixed with acidic or basic solutions (0.1-3\%), and the maximum amount of analyte should be eluted with the minimum volume of the solvent possible. ${ }^{14}$ The small solvent volume used in this step allows a considerable enrichment factor and a direct injection into the chromatographic systems. Furthermore, it also facilitates the on-line integration of the extraction and a consequent gain in terms of high-throughput and cost per analysis., ${ }^{3,4}$ Hence, MEPS can be used as a fully automated and miniaturized sample preparation procedure connected online with chromatographic devices (GC and LC) coupled to mass spectrometry without any or minimum modification of the existent hardware configurations. ${ }^{10}$ These facts are particularly important for the clinical environment, given the limited sample volumes available and the fast and high-throughput requirements. Beyond significant advantages in terms of speed and simplicity, MEPS may also reduce the carry-over and matrix effects that often affect the analysis of complex matrices. Moreover, the sorbent can be used for up to 100 extractions or more, depending on the matrices and target analytes involved (for some watered samples, MEPS can be used more than 400 times), whereas a SPE column is designed to be used once. ${ }^{3}$ Since its development, numerous sorbent materials were made commercially available for MEPS. These sorbents are essentially the traditional silica matrices (unmodified silica, $\mathrm{C}_{2}, \mathrm{C}_{8}$ and $\mathrm{C}_{18}$ ), the functionalized strong and weak cation and anion exchange $\mathrm{C}_{18}$ versions (SCX, SAX) and mixed sorbents $\left(\mathrm{C}_{8} /\right.$ SCX). More recently, the polymeric sorbent, polystyrene-divinylbenzene copolymer (PV-DVB), modified or functionalized to meet different retention abilities and target analytes, became available (Fig. 1). A detailed review about the properties of these sorbents has been provided by Pereira et al. ${ }^{6}$ As MEPS has a simple design, there is a very significant number of custom sorbents reported for MEPS, including restricted access materials (RAM) and molecular imprinted polymers (MIPs). However, these sorbents are not commercially available and so their use is still limited to proof of concept applications. But MEPS, like every sample extraction approach, presents some drawbacks, the most relevant being those associated with sorbent clogging and the consequent cavitation process. This is often reported in complex matrices with high protein and lipidic contents, resulting in poor recoveries and repeatability. ${ }^{15}$ Nevertheless, depending on the affinity of the selected sorbent to the target analytes, this problem can be greatly minimized by diluting the sample and performing several loading steps. This strategy has, however, an obvious cost of time.

\section{The MEPS architectures}

MEPS can be operated in different modes, the manual syringe being the format most often reported among the three types commercially available. Its simplicity, low-cost and easy design and operation are certain factors behind such popularity. ${ }^{6}$ As already mentioned, the experimental layout involved in a MEPS procedure is very simple (Fig. 1), but can be highly repetitive. Often, different steps (sorbent conditioning, sample loading, washing, elution, sorbent reconditioning) are repeated to optimize the extraction. In these cases, the minimization of user intervention using the semiautomatic (e-Vol ${ }^{\circledR}$ ) or automatic (autosamplers) MEPS architectures is critical to mitigate the experimental errors arising from the repetitive operation steps. As reviewed by Pereira et al., ${ }^{6,9}$ the semiautomatic and automatic versions of MEPS are very userfriendly, provide full customization of the extraction procedures and allow greater precision and higher automation, being more reliable than the manual versions. Overall, these features are particularly relevant to the pharmaceutical and clinical environments. ${ }^{10}$ Despite the higher costs of the semiautomatic and fully automatic MEPS architectures in comparison with the manual MEPS, the easy interchange between the three formats will certainly favour the former ones, leaving the manual MEPS mainly for small scale and exploratory projects.

\section{Application fields: from pharmaceutical and clinical analysis to food composition}

MEPS has been widely employed in different fields of research, encompassing clinical, forensic toxicology, and environmental and food analysis applications. This approach has been successfully applied for the extraction of a very broad range of analytes from different matrices. Considering only the last five years, MEPS applications cover the most diverse matrices, such as biological samples (urine, saliva, plasma or blood), water and wastewaters and several foods and beverages. Regarding the target analytes, a broad range of examples has also been reported involving different drugs (pharmaceuticals, drugs of abuse, pesticides, environmental contaminants, etc.) and bioactive compounds. These and other MEPS applications reported in the last five years in different fields of research will be discussed in more detail in the following sections.

\section{Pharmaceutical and clinical analysis}

New drugs are continuously being developed to be used in different aspects of our lives, particularly during disease treatment, and also to prevent or mitigate its development. This certainly demands equivalent analytical requirements to verify the effects these drugs may have in our health and environment and understand their therapeutic and toxic effects. ${ }^{16,17}$ In this context, analytical research plays a crucial role in assessing the quality of the pharmaceutical products, providing mandatory information about their purity, safety and metabolic fate in the biological samples in which they may be present. ${ }^{18}$ Parameters such as peak plasma drug concentration, clearance and bioavailability, for instance, must be known before a new drug can be approved. To measure these parameters, it is essential to know the levels of drug metabolites in the body fluids. In turn, this will allow the optimization of pharmacotherapy and will provide the basis for wider studies on patient compliance, bioavailability, pharmacoki- 
netics and genetics, organ function and influence of co-medication. ${ }^{17}$ There are nevertheless, at least three points which are crucial in the selection of the most suitable extraction procedure. Firstly, the complexity of the biological samples and the eventual presence of interfering elements (e.g. salts, acids, bases, proteins, and many organic compounds), which can mask or interfere with the compounds of interest and limit the direct analysis of the target analytes. ${ }^{17,19}$ Also, the concentrations in which the pharmaceuticals are generally found in our body and fluids justify an initial stage of preconcentration and purification of the target analytes prior to their analysis. ${ }^{20,21}$ Finally, in the pharmaceutical industry, sample preparation is frequently performed off-line and in fact, this is often a limiting step to achieve fast bioanalysis. As the number of samples grows, high-throughput and fully automated analytical techniques become essential. ${ }^{22}$ In this context, MEPS has gained popularity as an attractive and powerful sample-preparation approach suitable to fulfil these three challenges. ${ }^{5}$ In fact, this technique has been successfully used in the extraction of a wide variety of drug analytes, such as antidepressants, ${ }^{23}$ antibiotics ${ }^{24}$ anti-inflammatories, ${ }^{25}$ antidiabetics ${ }^{26}$ antipsychotics, ${ }^{27}$ and antiepileptics ${ }^{28}$ among others, from several biological matrices. ${ }^{23}$ As can be observed in Table 1, the silica-modified materials $\left(\mathrm{C}_{8}\right.$ and $\left.\mathrm{C}_{18}\right)$ are the MEPS sorbents most often reported in pharmaceutical and clinical applications. This is related to their ability to retain a wide range of compounds with different properties in a single sample extraction procedure. ${ }^{6}$ For this reason, in most MEPS applications reported in the literature, the $\mathrm{C}_{18}$ sorbent was selected without a comprehensive comparison of the efficiency of the remaining MEPS sorbents available. This includes pharmaceutical and clinical analysis reports on the extraction of different antibiotics, ${ }^{29}$ antifungics, ${ }^{30}$ cardiac drugs ${ }^{31}$ or the putative biomarker 4-hydroxynonenal. ${ }^{32}$ There are some studies, however, which involved the appropriate comparison of several MEPS sorbents and experimental conditions to support the definition of the best extraction conditions. Szultka et al.,${ }^{24}$ for instance, showed that among five sorbents, $\mathrm{C}_{2}, \mathrm{C}_{8}, \mathrm{C}_{18}, \mathrm{M} 1$ and pure silica (Sil), the $\mathrm{C}_{8}$ sorbent presented better selectivity and higher recovery for linezolid, while $\mathrm{C}_{18}$ showed the best performance for amoxicillin extraction. Similarly, Ferrone et al. $^{29}$ assayed the polymerics polystyrene divinylbenzene (SDVB) and the highly crosslinked PSDVB (HDVB), as well as Sil, $\mathrm{C}_{2}$ and $\mathrm{C}_{18}$, in the extraction of the antibiotics meropenem, linezolid, and levofloxacin. They also found that $\mathrm{C}_{18}$ was the best sorbent for the simultaneous extraction of the target analytes. These two examples show that the physicochemical properties of the analytes must be carefully considered when selecting the MEPS sorbent. ${ }^{7}$ Despite the wide application of $\mathrm{C}_{18}$, there are certainly many reports involving MEPS extraction whose analytical performance could be even better if a more extensive sorbent assay has been performed. This is particularly relevant if we remember that the polymeric sorbents present a higher loading capacity and lower selectivity, which make them particularly suitable for multiple residue extraction (reviewed by Pereira et al.). ${ }^{6}$ These sorbents became commercially available only in recent years and certainly this fact contributes to their less use than the silica counterparts. Following the MEPS extraction, most methods reported so far are coupled with a liquid chromatography analysis often complemented with an MS detection. This combination is an excellent analytical tool for the screening and determination of pharmaceutical drugs and their metabolites in biological samples. It is particularly suitable for drug metabolism studies, analysis and identification of impurities and degradation products, as well as the isolation and characterization of potential drug substances from natural synthetic sources. ${ }^{33,34}$ Ultimately, the use of tandem MS/MS in the MEPS/LC configuration creates a new standard in analytical performance and opens an avenue for broader applications. ${ }^{35,36}$ Meanwhile, the performance of MEPS has already been challenged with on-line LC-MS assays of drugs and metabolites in different biological samples. ${ }^{34}$ These online sample pre-treatment processes greatly speed up the analyses and were described for the first time by Moein et al. ${ }^{37}$ The authors reported the extraction and screening of sarcosine as a putative prostate-cancer marker in human plasma and urine samples, using DMIP-MEPS followed by LC-MS/MS. The results reported clearly showed that, despite the simplicity of the sample preparation procedure, the on-line MEPS approach enabled good selectivity and high sensitivity. Additionally, this work is also a good example of the development of promising sorbents, namely, molecularly-imprinted polymers (MIPs), exhibiting highly specific recognition abilities for target molecules. ${ }^{5,37,38}$ These materials have proven to be useful in many fields of chemistry or biology, mainly as selective sorbents for SPE. ${ }^{39-41}$ The LC-MS/MS configurations used are, nevertheless, very expensive and they are not available in many laboratories. For most routine analysis, cheaper configurations involving, for instance, UV detection, fit for the purpose, retrieving enough analytical performance, were used. The enrichment factor that MEPS allows, contributing to a very significant improvement of the detection and quantification limits of several compounds, is obviously determinant for such achievement. ${ }^{6}$ This comparison involving the use of MS versus UV detection can be clearly observed in the reports of Szultka et al. ${ }^{24}$ and Ferrone et al. ${ }^{29}$ Both groups proposed MEPS approaches for the extraction and quantification of different antibiotics in human plasma, but Szultka et al. ${ }^{24}$ used MS detection and reported ten times more sensitivity (Table 1). Nevertheless, the merit of the work reported by Ferrone et $a .^{29}$ is that the MEPS/UHPL-PDA methodology proposed was still useful for the therapeutic drug monitoring of the selected antibiotics and consequent critical evaluation of the dosage regimen given to the patients. This simplified configuration, MEPS/UHPLC-PDA, has also been reported by Alves et $a .^{23}$ and Gonçalves $e t ~ a l .{ }^{27}$ for the analysis of antidepressants and antipsychotics in urine, respectively.

The analysis of different aminated products in human samples, such as biogenic amines and several non-polar heterocyclic amines, constitutes a valuable source of metabolic information about several biological processes, including 
Table 1 Recent applications of MEPS in pharmaceutical and clinical analyses

\begin{tabular}{|c|c|c|c|c|c|c|c|c|}
\hline \multirow[b]{2}{*}{ Drug class (analytes) ${ }^{\text {ref }}$} & \multirow[b]{2}{*}{$\begin{array}{l}\text { Matrix (sample } \\
\text { volume, } \mu \mathrm{l})\end{array}$} & \multirow[b]{2}{*}{ MEPS sorbent/type } & \multicolumn{6}{|c|}{ Analytical performance } \\
\hline & & & Methodology & $\begin{array}{l}\text { Linear range } \\
\left(\mathrm{ng} \mathrm{ml} \mathrm{ml}^{-1}\right)\end{array}$ & Elution solvent ${ }^{*}(V, \mu \mathrm{l})$ & $\begin{array}{l}\mathrm{LOD} / \mathrm{LOQ} \\
\left(\mathrm{ng} \mathrm{ml} \mathrm{m}^{-1}\right)\end{array}$ & $\operatorname{RSD}(\%)$ & $\begin{array}{l}\text { Recovery } \\
(\%)\end{array}$ \\
\hline \multicolumn{9}{|l|}{ Agonists } \\
\hline BAM8-22, BAM22-8 ${ }^{44}$ & Plasma (50) & $\mathrm{C}_{8} /$ custom & LC-MS/MS & $\begin{array}{l}20-3045 \\
\left(\mathrm{nmol} \mathrm{l} \mathrm{l}^{-1}\right)\end{array}$ & $\begin{array}{l}95 \% \mathrm{MeOH}(0.25 \% \\
\left.\mathrm{NH}_{4} \mathrm{OH}\right)\end{array}$ & $-/ 20 \mathrm{nM}$ & $3-14$ & 85 \\
\hline \multicolumn{9}{|l|}{ Amines } \\
\hline $\begin{array}{l}\text { Biogenic amines ( } 12 \text { low molecular } \\
\text { weight and hydrophilic molecules } \\
\text { with a wide range of polarities) })^{43}\end{array}$ & $\begin{array}{l}\text { Plasma (100), } \\
\text { urine (50) }\end{array}$ & APS/eVol@ & HILIC-MS & $10-2000$ & $\begin{array}{l}\mathrm{MeOH}(0.1 \% \mathrm{FA})(3 \times \\
50)\end{array}$ & $2-5 / 10-20$ & $\begin{array}{l}<3.6 \\
<3.2\end{array}$ & $84-104$ \\
\hline $\begin{array}{l}\text { Biogenic amines }(\gamma \text {-amino butyric } \\
\text { acid, cadaverine, ornithine, putrescine, } \\
\text { spermidine })^{42}\end{array}$ & Urine (500) & $\mathrm{C}_{18} /$ online & PTV-GC-MS & $0-40$ & EtOH $(20)$ & $0.18-2.70 / 0.17-9$ & $<15$ & $90-113$ \\
\hline \multicolumn{9}{|l|}{ Analgesics and anti-inflammatories } \\
\hline $\begin{array}{l}\text { Dexamethasone, dexamethasone } \\
\text { disodium phosphate }{ }^{45}\end{array}$ & $\begin{array}{l}\text { Aqueous } \\
\text { humor (50) }\end{array}$ & $\mathrm{C}_{18} / \mathrm{eVol} \circledast$ & LC-MS/MS & $0.5-150$ & $\mathrm{MeOH}$ & $-/ 0.5-0.7$ & $4-16$ & 91-119 \\
\hline \multicolumn{9}{|c|}{ NSAIDs (non-steroidal anti-inflammatory drugs) } \\
\hline $\begin{array}{l}\text { Acetylsalicylic acid, diclofenac, } \\
\text { ibuprofen, ketoprofen, naproxen }\end{array}$ & Urine $(20)$ & $\mathrm{C}_{18} / \mathrm{eVol} \circledast$ & UHPLC-UV & $5-20000$ & $\mathrm{ACN}(\mathrm{pH} 8.0)(20)$ & $\begin{array}{l}1.07-16.2 / \\
3.21-48.7\end{array}$ & $0.503-9.27$ & 89-107 \\
\hline $\begin{array}{l}\text { Fenbufen, flurbiprofen, furprofen, } \\
\text { ibuprofen, indomethacin, indoprofen, } \\
\text { ketoprofen }{ }^{47}\end{array}$ & $\begin{array}{l}\text { Plasma, urine } \\
\text { (85) }\end{array}$ & $\mathrm{C}_{18} / \mathrm{eVol}{ }^{\circledR}$ & HPLC-PDA & $1-10000$ & $\begin{array}{l}95 \% \mathrm{MeOH}:(0.1 \% \\
\mathrm{NaOH})\end{array}$ & $30 /$ f100 & $\begin{array}{l}0.07-11.1 \\
0.59-10.8\end{array}$ & - \\
\hline $\begin{array}{l}\text { Carprofen, fenbufen, flurbiprofen, } \\
\text { ibuprofen, indomethacin, indoprofen, } \\
\text { ketoprofen }{ }^{48}\end{array}$ & $\begin{array}{l}\text { Human } \\
\text { dialysates }\end{array}$ & $\mathrm{C}_{18} /$ custom & UHPLC-DAD & $25-15000$ & $\begin{array}{l}\mathrm{MeOH}: 1 \% \mathrm{NaOH} \\
(95: 5)\end{array}$ & $8-10 / 25-33$ & $0.10-7.69$ & $94-100$ \\
\hline Several NSAIDs (7) and FLQs $(4)^{25}$ & Urine (180) & $\mathrm{C}_{18} /$ manual & UHPLC-PDA & $100-10000$ & $\mathrm{MeOH}(8 \times 25)$ & $\begin{array}{l}1.07-16.2 / \\
3.21-48.7\end{array}$ & $<20$ & 89-107 \\
\hline \multicolumn{9}{|l|}{ Antibiotics } \\
\hline Amoxicillin, linezolid ${ }^{24}$ & Plasma (50) & $\begin{array}{l}\text { Sil, } \mathrm{C}_{2}, \mathbf{C}_{\mathbf{8}}, \mathbf{C}_{\mathbf{1 8}}, \mathrm{M} 1 / \\
\text { manual }\end{array}$ & LC-MS/MS & $1-50000$ & $\mathrm{MeOH}$ & $\begin{array}{l}0.1341-0.1407 / \\
0.3814-0.4249\end{array}$ & $0.24-6.83$ & 70 \\
\hline Levofloxacin, linezolid, meropenem $^{29}$ & Plasma & $\begin{array}{l}\text { Sil, } \mathrm{C}_{2}, \mathrm{C}_{8}, \mathbf{C}_{\mathbf{1 8}} \\
\text { SDVB, HDVB/ } \\
\text { manual }\end{array}$ & UHPLC-PDA & $10-30000$ & $\mathrm{MeOH}(150)$ & $-/ 10-20$ & $\leq 9.76$ & $92-98$ \\
\hline Ciprofloxacin, levofloxacin ${ }^{49}$ & $\begin{array}{l}\text { Sputum (cystic } \\
\text { fibrosis } \\
\text { patients) }\end{array}$ & $\mathrm{C}_{18} / \mathrm{eVol}{ }^{\circledR}$ & HPLC-PDA & $50-2000$ & $\mathrm{MeOH}(20)$ & $-/ 50$ & $1.75-11.1$ & - \\
\hline Ulifloxacin $^{50}$ & $\begin{array}{l}\text { Plasma, urine } \\
\text { (50) }\end{array}$ & $\mathrm{C}_{18} / \mathrm{eVol}{ }^{\circledR}$ & UHPLC-PDA & $20-10000$ & $\mathrm{MeOH}(150)$ & $-/ 20$ & $0.49-6.74$ & 95 \\
\hline \multicolumn{9}{|l|}{ Antidepressants } \\
\hline Agomelatine $^{51}$ & $\begin{array}{l}\text { Plasma, saliva } \\
(50)\end{array}$ & $\mathrm{C}_{8} /$ manual & HPLC-FLD & $0.5-25$ & $\mathrm{MeOH}$ & $0.15 /-$ & $3.40-4.53$ & $90-99$ \\
\hline $\begin{array}{l}\text { Citalopram, clomipramine, } \\
\text { fluoxetine, imipramine, mirtazapine, } \\
\text { paroxetine, sertraline }{ }^{52}\end{array}$ & Plasma (200) & Monolithic/manual & LC-MS/MS & $5-850$ & $\mathrm{MeOH}: \mathrm{ACN}(100)$ & $-/ 0.05-100$ & $0.4-14.3$ & - \\
\hline $\begin{array}{l}\text { Clomipramine, } \\
\text { desmethylclomipramine, fluoxetine, } \\
\text { norfluoxetine }{ }^{23}\end{array}$ & Urine (500) & $\mathrm{C}_{18} / \mathrm{eVol}{ }^{\circledR}$ & UHPLC-PDA & $100-5000$ & $\mathrm{MeOH}: \mathrm{ACN}(80: 20)$ & $68-87 / 100$ & $3.0-8.5$ & $84-99$ \\
\hline $\begin{array}{l}\text { Citalopram, fluoxetine, paroxetine, } \\
\text { sertraline }^{53}\end{array}$ & Plasma (400) & M1 manual & CE-DAD & $20-500$ & $\begin{array}{l}55 \% \mathrm{MeOH} / \mathrm{P} \text { buffer } \\
\left(50 \mathrm{mmol} \mathrm{l}^{-1}, \mathrm{pH} 4.5\right)\end{array}$ & $-/ 20-30$ & $2.9-8.7$ & - \\
\hline
\end{tabular}


Analytical performance

\begin{tabular}{|c|c|c|c|c|c|c|c|c|}
\hline Drug class (analytes) ${ }^{\text {ref }}$ & $\begin{array}{l}\text { Matrix (sample } \\
\text { volume, } \mu \mathrm{l})\end{array}$ & MEPS sorbent/type & Methodology & $\begin{array}{l}\text { Linear range } \\
\left(\mathrm{ng} \mathrm{ml}^{-1}\right)\end{array}$ & Elution solvent ${ }^{*}(V, \mu \mathrm{l})$ & $\begin{array}{l}\text { LOD/LOQ } \\
\left(\mathrm{ng} \mathrm{ml}^{-1}\right)\end{array}$ & RSD (\%) & $\begin{array}{l}\text { Recovery } \\
(\%)\end{array}$ \\
\hline $\begin{array}{l}\text { Fluoxetine, norfluoxetine, } \\
\text { paroxetine }^{54}\end{array}$ & $\begin{array}{l}\text { Plasma (500, } \\
\text { patients with } \\
\text { depression) }\end{array}$ & $\mathrm{C}_{18} /$ manual & LC-FLD & $5-750$ & $\begin{array}{l}\mathrm{MeOH}(1 \% \mathrm{FA})(5 \times \\
200)\end{array}$ & $-1-$ & $\leq 13.6$ & $59-77$ \\
\hline$O$-Desmethylvenlafaxine, venlafaxine ${ }^{55}$ & Plasma (100) & $\mathrm{C}_{18} /$ manual & LC-FLD & $10-1000$ & $\mathrm{MeOH}$ & $-/ 10-20$ & $1.3-5.1$ & $72-83$ \\
\hline $\begin{array}{l}\text { Antidiabetics (chlorpropamide, } \\
\text { glimepiride, gliclazide) }{ }^{26} \\
\text { Antidyslipidemics }\end{array}$ & Plasma (100) & $\mathrm{C}_{18} /$ manual & HPLC-DAD & $100-50000$ & $70 \% \mathrm{ACN}$ & $-/ 100-1000$ & $0.8-11.3$ & $37-72$ \\
\hline $\begin{array}{l}\text { Multistatin analysis ( } 7 \text { clinically } \\
\text { relevant statins, their interconversion } \\
\text { products and metabolites })^{11} \\
\text { Antiepileptics/anticonvulsants }\end{array}$ & Serum $(50)$ & $\mathrm{C}_{8} /$ manual & UHPLC-MS & $0.1-1000$ & $\begin{array}{l}\mathrm{ACN}: \mathrm{NH}_{4} \mathrm{CH}_{3} \mathrm{CO}_{2} \\
(0.01 \mathrm{M}, \mathrm{pH} 4.5)(5: 95) \\
(100)\end{array}$ & $-/ 10$ & $0.3-19.2$ & 79-119 \\
\hline $\begin{array}{l}\text { Carbamazepine; carbamazepine-10,11- } \\
\text { epoxide; licarbazepine; lamotrigine; } \\
\text { oxcarbazepine; phenytoin, } \\
\text { phenobarbital }^{56}\end{array}$ & Plasma (100) & $\mathrm{C}_{18} /$ manual & HPLC-DAD & $100-40000$ & $\mathrm{MeOH}(2 \times 30)$ & $10-90 / 100-400$ & $0.6-17.7$ & $57-98$ \\
\hline $\begin{array}{l}\text { Carbamazepine, dexamethasone, } \\
\text { naproxen }\end{array}$ & Urine (100) & $\begin{array}{l}\text { Polymer network/ } \\
\text { manual }\end{array}$ & HPLC-DAD & $4.2-500$ & $\mathrm{MeOH}$ & $1.3-1.5 / 4.2-5.0$ & $1.3-7.4$ & - \\
\hline Carbamazepine, lamotrigine ${ }^{52}$ & Plasma (200) & Monolithic/manual & LC-MS/MS & $0.5-10500$ & $\mathrm{MeOH}$ : ACN (100) & $-/ 0.05-100$ & $0.2-14.4$ & - \\
\hline Lamotrigine $^{58}$ & $\begin{array}{l}\text { Rat plasma } \\
\text { and brain }(100)\end{array}$ & $\mathrm{C}_{18} / \mathrm{eVol}{ }^{\circledR}$ & HPLC-DAD & $0.100-20000$ & $\mathrm{MeOH}(2 \times 30)$ & $-/ 10-500$ & $1.0-8.6$ & $68-87$ \\
\hline $\begin{array}{l}\text { Zonisamide }{ }^{28} \\
\text { Antifungics }\end{array}$ & Plasma (100) & $\mathrm{C}_{18} /$ manual & HPLC-DAD & $200-80000$ & ACN & $-/ 200$ & $1.5-13.3$ & $63-65$ \\
\hline Imidazole and triazole drugs $(12)^{30}$ & $\begin{array}{l}\text { Plasma (150), } \\
\text { urine (200) }\end{array}$ & $\mathrm{C}_{\mathbf{1 8}} /$ manual & HPLC-DAD & $20-5000$ & $\mathrm{MeOH}(8 \times 25)$ & $7-70 / 20-200$ & $1.47-13.4$ & - \\
\hline \multicolumn{9}{|l|}{ Antihypertensives and antiarrhythmics } \\
\hline Amiodarone, desethylamiodarone ${ }^{59}$ & Plasma (100) & $\mathrm{C}_{18} /$ manual & HPLC-DAD & $1-10000$ & $\mathrm{MeOH}: \mathrm{FA}(95: 5)(100)$ & $20 / 100$ & $0.94-5.16$ & $59-68$ \\
\hline Metoprolol enantiomers $^{60}$ & $\begin{array}{l}\text { Plasma, saliva } \\
(100)\end{array}$ & $\begin{array}{l}\mathrm{C}_{4}, \mathrm{C}_{8}, \mathrm{C}_{18} \text {, polysor- } \\
\text { bate/manual }\end{array}$ & LC/MS & $2.5-500$ & IPA $(200)$ & $0.5-1.5 /-$ & $2.25-4.56$ & $93-97$ \\
\hline Acebutolol, metoprolol ${ }^{61}$ & Plasma & $\begin{array}{l}\text { Carbon-XCOS/ } \\
\text { online }\end{array}$ & LC-MS/MS & $10-2000(\mathrm{nM})$ & $\mathrm{MeOH}(0.1 \% \mathrm{FA})$ & $10 /-(\mathrm{nM})$ & $4.4-14.4$ & $80-90$ \\
\hline \multicolumn{9}{|l|}{ Antipsychotics } \\
\hline $\begin{array}{l}\text { 9-Hydroxyrispiridone, clozapine, } \\
\text { norclozapine, rispiridone }{ }^{27}\end{array}$ & Urine (500) & $\mathrm{C}_{18} / \mathrm{eVol}{ }^{\circledR}$ & UHPLC-PDA & $100-5000$ & $\begin{array}{l}\mathrm{MeOH}: \mathrm{ACN}: \mathrm{H}_{2} \mathrm{O}(2 \times \\
500)\end{array}$ & $52-55 / 100$ & $2.65-18$ & 76-96 \\
\hline $\begin{array}{l}\text { Clozapine, chlorpromazine, } \\
\text { haloperidol, olanzapine, quetiapine }\end{array}$ & Plasma (200) & $\begin{array}{l}\text { Hybrid silica } \\
\text { monoliths/manual }\end{array}$ & LC-MS/MS & $0.5-1550$ & $\mathrm{MeOH}: \mathrm{ACN}(100)$ & $-/ 0.05-10$ & $0.2-13.9$ & - \\
\hline $\begin{array}{l}\text { Chlorpromazine, clozapine, } \\
\text { cyamemazine, haloperidol, } \\
\text { levomepromazine, olanzapine, } \\
\text { quetiapine }^{62}\end{array}$ & Plasma (250) & M1/manual & GC-MS/MS & $0.8-1000$ & $\begin{array}{l}\mathrm{MeOH}: \mathrm{NH}_{3}(95: 5) \\
(200)\end{array}$ & $0.2-1.0 / 1000$ & $0.24-10.67$ & $62-92$ \\
\hline Ziprazidone $^{63}$ & Plasma (100) & $\mathrm{C}_{2} /$ manual & HPLC-UV & $1-500$ & $\mathrm{MeOH}$ & $0.3 / 1.0$ & $3.0-4.1$ & $92-95$ \\
\hline Antivirals (entecavir) ${ }^{64}$ & Plasma (50) & PGC/eVol@ & $\begin{array}{l}\text { HILIC-UHPLC-MS/ } \\
\text { MS }\end{array}$ & $0.1-100$ & $75 \%$ ACN (100) & $0.15-0.3 / 0.5-1.0$ & $0.9-17.4$ & $80-106$ \\
\hline Anxiolytics (clonazepam, diazepam) ${ }^{52}$ & Plasma (50) & PGC/eVol@ & $\begin{array}{l}\text { HILIC-UHPLC-MS/ } \\
\text { MS }\end{array}$ & $5-850$ & $\mathrm{MeOH}: \mathrm{ACN}(100)$ & $-/ 0.05-0.10$ & $1.5-13.5$ & - \\
\hline \multicolumn{9}{|l|}{ Cardiacs } \\
\hline Acylcarnitines, carnitine ${ }^{31}$ & Urine (100) & $\begin{array}{l}\mathrm{C}_{2}, \mathrm{C}_{8}, \mathrm{C}_{18}, \mathrm{M} 1, \mathrm{C}_{2} \\
+\mathrm{M1} / \mathrm{eVol}{ }^{\circledR}\end{array}$ & $\begin{array}{l}\text { HILIC-UHPLC-MS/ } \\
\text { MS }\end{array}$ & $0.1-500$ & $\begin{array}{l}\text { ACN (C2), } 20 \mathrm{mM} \\
\text { pyridine/ACN (M1) }\end{array}$ & $0.1 /-$ & $0.8-9.4$ & - \\
\hline Aliskiren, prasugrel, rivaroxaban ${ }^{65}$ & Urine (200) & $\mathrm{C}_{8} /$ manual & UHPLC-MS/MS & $0.0005-1000$ & $\mathrm{MeOH}(100)$ & $-/ 0.005-0.0005$ & $0.96-7.12$ & $98-100$ \\
\hline
\end{tabular}


Analytical performance

\begin{tabular}{|c|c|c|c|c|c|c|c|c|}
\hline Drug class (analytes) ${ }^{\text {ref }}$ & $\begin{array}{l}\text { Matrix (sample } \\
\text { volume, } \mu \mathrm{l})\end{array}$ & MEPS sorbent/type & Methodology & $\begin{array}{l}\text { Linear range } \\
\left(\mathrm{ng} \mathrm{ml}^{-1}\right)\end{array}$ & Elution solvent ${ }^{*}(V, \mu \mathrm{l})$ & $\begin{array}{l}\mathrm{LOD} / \mathrm{LOQ} \\
\left(\mathrm{ng} \mathrm{ml^{-1 }}\right)\end{array}$ & $\operatorname{RSD}(\%)$ & $\begin{array}{l}\text { Recovery } \\
(\%)\end{array}$ \\
\hline Aliskiren, enalapril, enalaprilat ${ }^{66}$ & $\begin{array}{l}\text { Plasma and } \\
\text { urine (50) }\end{array}$ & $\mathrm{C}_{8} / \mathrm{eVol} \circledast$ & UHPLC-MS/MS & $0.01-500$ & $\mathrm{MeOH}(100)$ & $-/ 0.01$ & $0.3-9.6$ & $75-93$ \\
\hline Betaxolol $^{67}$ & Urine & $\mathrm{C}_{18} /$ online & SIC-FLD & $5-400$ & $\begin{array}{l}\text { ACN: } 0.5 \% \\
\text { triethylamine }(\mathrm{pH} 4.5) \\
(30: 70)\end{array}$ & $1.5 / 5$ & $1-4$ & $100-108$ \\
\hline \multicolumn{9}{|l|}{ Local anaesthetics } \\
\hline $\begin{array}{l}\text { Bupivacaine, lidocaine, mepivacaine, } \\
\text { ropivacaine }^{68}\end{array}$ & $\begin{array}{l}\text { Plasma, urine } \\
(100)\end{array}$ & MIPs/manual & LC-MS/MS & $\begin{array}{l}5.0-2000 \\
(\mathrm{nM})\end{array}$ & $\begin{array}{l}60 \%(\mathrm{MeOH} / 0.25 \% \\
\left.\mathrm{NH}_{4} \mathrm{OH}\right)\end{array}$ & $1.0 / 5.0(\mathrm{nM})$ & $0.7-14.0$ & $60-80$ \\
\hline Lidocaine, prilocaine, ropivacaine ${ }^{69}$ & Plasma, saliva & $\begin{array}{l}\text { Reduced graphene } \\
\text { oxide/manual }\end{array}$ & LC-MS/MS & $5-2000(\mathrm{nM})$ & $\begin{array}{l}\mathrm{MeOH}: \mathrm{FA}(90: 10)(2 \times \\
100)\end{array}$ & $2.0-4.0 / 5.0(\mathrm{nM})$ & $2.39-19.14$ & $95-106$ \\
\hline \multicolumn{9}{|l|}{ Putative disease biomarkers } \\
\hline $\begin{array}{l}\text { 5-Hydroxymethyluracil; 8-hydroxy-2'- } \\
\text { deoxyguanosine; malondialdehyde, } \\
\text { uric acid }^{70}\end{array}$ & Urine $(50)$ & $\mathrm{C}_{8} / \mathrm{eVol} \circledast$ & UHPLC-PDA & $0.5-250000$ & $\begin{array}{l}0.01 \% \text { FA }(5 \times 50), 20 \% \\
\text { MeOH } / 0.01 \% \text { FA }(3 \times \\
50)\end{array}$ & $\begin{array}{l}0.05-720 / \\
0.23-2310\end{array}$ & $1.0-8.3$ & $91-104$ \\
\hline $\begin{array}{l}\text { 5-Hydroxymethyluracil; 8-oxo-7,8- } \\
\text { dihydro-2'-deoxyguanosine } \text { f1 }^{71}\end{array}$ & Urine (250) & $\mathrm{C}_{8} / \mathrm{eVol}{ }^{\circledR}$ & UHPLC-PDA & $0.5-5000$ & $\mathrm{MeOH}(0.01 \%$ FA) (90) & $0.05-40 / 0.23-130$ & $0.9-8.3$ & $64-102$ \\
\hline 4-Hydroxynonenal ${ }^{32}$ & & $\begin{array}{l}\mathrm{C}_{2}, \mathrm{C}_{8}, \mathrm{C}_{\mathbf{1 8}}, \mathrm{M} 1 \text { and } \\
\text { SIL/manual }\end{array}$ & HPLC-UV & $30-500(\mathrm{nM})$ & ACN (100 150) & 4.5/9.0 $(\mu \mathrm{M})$ & 1.30 & $47-89$ \\
\hline Eicosanoids $^{72}$ & Urine (250) & $\begin{array}{l}\mathrm{C}_{2}, \mathrm{C}_{8}, \mathrm{C}_{18}, \mathrm{Sil}, \mathrm{M} 1, \\
\text { PEP, VAX, RAX, } \\
\text { RCX, PGC, } \\
\text { HLB-DVB/eVol }{ }^{\circ}\end{array}$ & UHPLC-PDA & $0.1-300$ & $\mathrm{MeOH}(2 \times 50)$ & $\begin{array}{l}0.04-1.12 / \\
0.10-2.11\end{array}$ & $1.29-10.43$ & $>95$ \\
\hline Sarcosine $\mathrm{e}^{37}$ & $\begin{array}{l}\text { Plasma (100), } \\
\text { urine (100) }\end{array}$ & DMIP/online & LC-MS/MS & $3.0-10000$ & $80 \%$ ACN (100) & $-/ 1.0-3.0$ & $2.9-7.1$ & $87-89$ \\
\hline $\begin{array}{l}\text { Preservatives (benzyl-, butyl-, ethyl-, } \\
\text { methyl- and propyl-parabens) }\end{array}$ & Urine (200) & $\mathrm{C}_{18} /$ manual & UHPLC-MS/MS & $0.5-50$ & 80\% МeOH (50) & $-/ 0.5$ & $4.3-15$ & - \\
\hline $\begin{array}{l}\text { Others (AZD6118, candidate drugs } \\
\text { against cognitive disorders) }^{74}\end{array}$ & Dog plasma & $\mathrm{M} 1 / \mathrm{eVol} \circledast$ & UHPLC-MS/MS & $\begin{array}{l}20-25000 \\
(\mathrm{nM})\end{array}$ & $\begin{array}{l}60 \%(\mathrm{MeOH} / 3 \% \\
\left.\mathrm{NH}_{4} \mathrm{OH}\right)(50)\end{array}$ & $-1-$ & $1.9-3.2$ & - \\
\hline
\end{tabular}

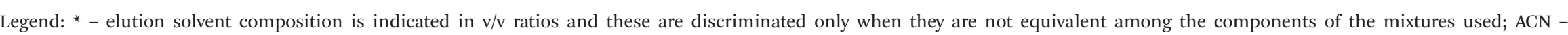

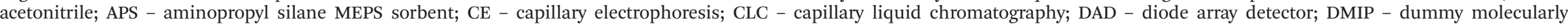

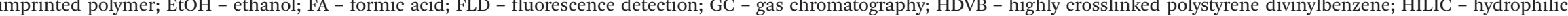

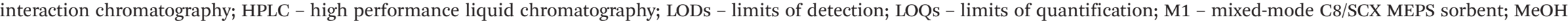

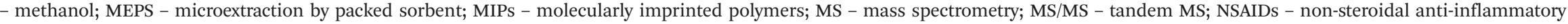

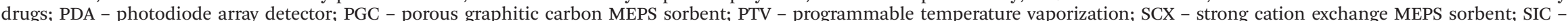

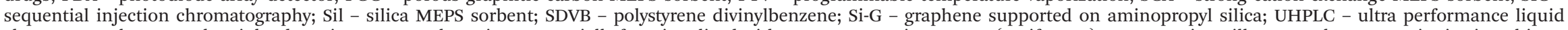
chromatography; UV - ultraviolet detection; VAX - polymeric DVB partially functionalized with quaternary amine groups (Verify® AX); $\mu$ PESI - micropillar array electrospray ionization chip. 
pathological conditions. Regarding this, it is very interesting to verify that different biogenic amines extracted from plasma and urine using MEPS were analysed using distinct approaches such as HILIC-MS, PTV-GC-MS and CLC-MS. ${ }^{42,43}$ This is also indirect evidence of the wide compatibility of MEPS with different analytical methodologies. These reports highlight the broad usage and potential of MEPS extraction in the analytical layout supporting pharmaceutical and clinical analysis. For an extended analysis, please follow Table 1.

\section{Pesticides and environmental contaminants}

The use of pesticides in modern agriculture is an indispensable measure to protect crops from diseases and pests, therefore ensuring their economic viability. ${ }^{75,76}$ Pesticide usage, however, is not limited to industrial applications, being nowadays also widespread in homegrown applications. For this reason, there are more than 1100 active compounds registered and available in the European Union (EU) markets! ${ }^{77}$ However, pesticides are simultaneously harmful to the environment (e.g. soils, surface and ground waters) and potentially dangerous to human health. ${ }^{76,78}$ Compounds such as atrazine, metribuzin and bifenthrin can cause endocrine disruption, ${ }^{78}$ and chronic exposure to different pesticides may result in genotoxic, mutagenic and carcinogenic events, ${ }^{79,80}$ as well as congenital malformations and degenerative diseases at the beginning of embryonic development. ${ }^{81-83}$ Organochlorines (OCPs) and organophosphorus (OPPs), for instance, are widely known as environmental contaminants. ${ }^{77,84}$ In fact, OCPs are one of the most persistent organic pollutants (POPs) present in the environment, and their monitorization and control is important not only for the protection of the environment, but also for human health. ${ }^{77}$ In this context, different methods using MEPS coupled to GC-MS have been reported to analyse several OCPs (Table 2). Taghani et al., for instance, proposed nanodiatomite $^{77}$ and carboxyl-purified multiwalled carbon nanotubes $(\mathrm{CNTs})^{84}$ as sorbents for the preconcentration of several OCPs (Table 2). In turn, Kaur et al. ${ }^{75}$ used the $\mathrm{C}_{18}$ MEPS sorbent to extract endosulfan and its metabolites in tap water. Endosulfan is a broad-spectrum chlorinated cyclodiene insecticide widely applied to cereals, fruits and vegetables and its quantification was achieved with good analytical performance (good linearity, lower limits of detection (LODs) and quantification (LOQs) and high recoveries). ${ }^{75}$ OPPs appeared as substitutes to other pesticides, mainly OCPs. Their application increased in agriculture to control insects and pests due to their lack of bioaccumulation in ecosystems. Nevertheless, OPPs are still toxic to humans and potentially mutagenic and carcinogenic. ${ }^{80,85}$ Diazinon, for instance, due to its wide use in agriculture, became a major environmental contaminant, namely aqueous matrices, and its monitorization is therefore very important. Accordingly, several authors customized different MEPS sorbents to achieve suitable methods to extract this and other OPPs. Taghani et al. ${ }^{86}$ for instance, used nanoperlite, while Saraji et ll. $^{80}$ used a new porous composite of nanoclay and polysiloxane. These reports attained an excellent analytical performance in water sample analysis, but Santos et $a l .{ }^{85}$ raised the challenge by reporting a MEPS/GC-MS/MS approach to determine OPPs in whole blood. Synthetic pyrethroids are being adopted to replace toxic OPP insecticides and persistent OCPs. Once again, their impact on human health and the definition of safety limits is still a matter of debate. In this context, Klimowska and Wielgomas ${ }^{87}$ proposed a fast MEPS followed by large volume injection-gas chromatography-mass spectrometry (MEPS-LVI-GC-MS) for the determination of pyrethroid metabolites in human urine. At another level, the prevalence of several environmental contaminants in air, soil, sediments and water, such as polycyclic aromatic hydrocarbons (PAHs), polychlorinated biphenyl (PCBs), brominated diphenyl ethers (BDEs), phthalate esters (PEs), nonylphenols, bisphenols, steroid hormones, and nitro and musk compounds, among others, has generated increasing public concerns, since most of these compounds promote mutagenic and carcinogenic events, even when present at trace levels. For this reason, the release of such contaminants to the environment should be closely monitored. Certainly with this goal in mind, Quinto et al. ${ }^{88}$ reported an optimized MEPS/GC-MS procedure to accurately quantify PAHs in aqueous samples. BDEs are flame retardants that have been classified as POPs by the Stockholm Convention (http://chm.pops.int/TheConvention/ ThePOPs/TheNewPOPs/tabid/2511/Default.aspx). To assay the presence of such compounds in sewage sludge, MartínezMoral et al. ${ }^{89}$ reported a method based on selective pressurized liquid extraction followed by MEPS/GC-MS/MS. A similar application was developed by Naccarato et al. ${ }^{90}$ to extract a specific class of BDEs, the organophosphate ester flame retardants (OPFRs), from environmental waters. The authors assayed several MEPS cartridges and solvents and reported divinylbenzene (DVB) and acetonitrile as the best sorbent material and elution solvent, respectively. Phthalate acid esters (PAE) are extensively used in consumables, household and personal care products (PCP), generating a 6.0 million tons annual production worldwide. ${ }^{91}$ Due to their potential risks to the environment and human health, PAEs have been placed in the priority pollutant list issued by the EU and the United States Environmental Protection Agency (USEPA). ${ }^{92}$ To target these compounds, Amiri et al. ${ }^{92}$ synthesized nanohydroxyapatite (HAP) and used it as an efficient MEPS sorbent for the PAE extraction from water samples. Currently, increasing attention is also being paid to the monitorization and control of musk compounds commonly used as additives in many products, as PCPs and detergents. Due to their extensive use, musk products have become emerging organic contaminants (EOCs) and have already been detected in diverse environmental matrices. Caballero-Díaz et al., ${ }^{93}$ for instance, combined MEPS with surface-enhanced Raman spectroscopy (SERS) for the determination of musk ketone (MK) in river water samples. The MEPS/LVI-GC-MS is, nevertheless, the most popular approach for this application. Cavalheiro et al. ${ }^{94}$ for instance, proposed it for the simultaneous determination of nitro and polycyclic musk compounds in estuarine and wastewater samples. Aromatic amines are another chemical group classified as environmental water pollutants due to their toxicity, 


\begin{tabular}{|c|c|c|c|c|c|c|c|c|}
\hline \multirow[b]{2}{*}{ Environmental contaminant classes (analytes) ${ }^{\mathrm{Ref}}$} & \multirow{2}{*}{$\begin{array}{l}\text { Matrix }{ }^{\text {Ref }} \\
\text { (sample } \\
\text { volume, } \mu \mathrm{l} \text { ) }\end{array}$} & \multirow[b]{2}{*}{$\begin{array}{l}\text { MEPS } \\
\text { sorbent/type }\end{array}$} & \multicolumn{6}{|c|}{ Analytical performance } \\
\hline & & & Methodology & $\begin{array}{l}\text { Linear range } \\
\left({\left.\text { ng } l^{-1}\right)}^{-1}\right.\end{array}$ & $\begin{array}{l}\text { Elution } \\
\text { solvent }^{*}(V, \mu \mathrm{l})\end{array}$ & LOD/LOQ (ng ml $\left.{ }^{-1}\right)$ & RSD (\%) & $\begin{array}{l}\text { Recovery } \\
(\%)\end{array}$ \\
\hline Aromatic amines (Azo dye derivatives) ${ }^{95}$ & $\begin{array}{l}\text { Textiles } \\
(200 \mathrm{mg})\end{array}$ & $\mathrm{PEP} / \mathrm{eVol} \circledast$ & GC-MS & $0.040-989$ & 1-Propanol (60) & $0.040-42 / 0.13-139$ & $<15$ & $1-96$ \\
\hline BDEs (BDE-3, $-10,-28,-47,-99,-100,-154)^{89}$ & Water (100) & $\begin{array}{l}\mathrm{C}_{18} / \\
\text { autosampler }\end{array}$ & GC-MS/MS & $\begin{array}{l}0.06-1.2(\mathrm{ng} \\
\left.\mathrm{g}^{-1}\right)\end{array}$ & $n$-Hex (100) & $\begin{array}{l}0.0004-0.003 / \\
0.0007-0.006\end{array}$ & $<7$ & $92-102$ \\
\hline $\begin{array}{l}\text { Chlorophenols (2-chlorophenol; 2,4- } \\
\text { dichlorophenol; 2,4,6-trichlorophenol and } \\
\text { 4-chloro-3-methylphenol) }\end{array}$ & Soil (20 g) & $\begin{array}{l}\mathrm{C}_{18} / \\
\text { autosampler }\end{array}$ & GC-MS & $1-12\left(\mu \mathrm{g} \mathrm{kg}{ }^{-1}\right)$ & EtAc (10) & $\begin{array}{l}0.118-0.894 / \\
0.353-2.683\left(\mu \mathrm{g} \mathrm{kg}{ }^{-1}\right)\end{array}$ & $<10$ & $13-23$ \\
\hline Chlorobenzenes (12 derivatives) ${ }^{96}$ & Water $(1.75 \mathrm{ml})$ & $\begin{array}{l}\mathrm{C}_{18} / \\
\text { autosampler }\end{array}$ & PTV-GC-MS & $0.0003-500$ & Hex : acetone (25) & $0.0003-0.07 / 0.001-0.2$ & $<12$ & $26-81$ \\
\hline Dinotefuran $^{106}$ & $\begin{array}{l}\text { Water, artificial } \\
\text { saliva }(200)\end{array}$ & MIPs/- & HPLC-DAD & - & IPA (200) & $-1-$ & $<8.70$ & $89-92$ \\
\hline \multicolumn{9}{|l|}{ Endocrine disrupting chemicals (EDCs) } \\
\hline Aldicarb, dimethoate, propazine, terbutryn ${ }^{97}$ & $\begin{array}{l}\text { Urine (1), tap } \\
\text { water }(1) \text {, soil } \\
(2 \mathrm{~g})\end{array}$ & $\mathrm{C}_{18} /$ manual & HPLC-UV & $1-500$ & $\mathrm{MeOH}(30)$ & $0.05-0.58 / 0.175-1.98$ & $<6.3$ & $81-98$ \\
\hline \multirow[t]{2}{*}{ Benzyl, butyl, ethyl, methyl and propyl parabens } & Water $^{99}(3.6)$ & Si-G/manual & HPLC - UV & $0.2-20$ & $\mathrm{ACN}: \mathrm{MeOH}$ & $0.06-0.09 / 0.2-0.3$ & $\begin{array}{l}1.5 \text { to } \\
19.2\end{array}$ & $82-119$ \\
\hline & Urine $^{73}(0.4)$ & $\mathrm{C}_{18} /$ manual & $\begin{array}{l}\text { UHPLC-MS/ } \\
\text { MS }\end{array}$ & $0.5-50$ & $80 \% \mathrm{MeOH}$ & $-/ 0.5-50$ & $<15$ & - \\
\hline Mandelic acid 107,108 & Urine (800) & MIPs/manual & HPLC-UV & $15-2000$ & $\begin{array}{l}\text { EtOH-acetic acid } \\
(80: 20)(2 \times 100)\end{array}$ & $60 / 200$ & $3.4-6.6$ & 88 \\
\hline $\begin{array}{l}\text { HAAs (dibromo-, dichloro-, monobromo-, } \\
\text { monochloro-, trichloroacetic acid) }{ }^{100} \\
\text { Musk compounds }\end{array}$ & Water (2.5) & $\begin{array}{l}\mathrm{C}_{18} / \\
\text { autosampler }\end{array}$ & PTV-GC-MS & $0.36-300$ & MTBE (20) & $0.36-1.2 / 1.2-3.6$ & $4.2-14$ & $83-117$ \\
\hline $\begin{array}{l}\text { Cashmeran, celestolide, galaxolide, musk } \\
\text { ambrette, musk ketone, musk mosken, } \\
\text { phantolide, tonalide, traseolide }{ }^{94}\end{array}$ & Water $(5.5 \mathrm{ml})$ & $\begin{array}{l}\mathrm{C}_{18} / \\
\text { autosampler }\end{array}$ & LVI-GC-MS & $0.005-2.5$ & Acetate $: n$-hex (25) & $0.005-0.084 /-$ & $<13.2$ & 75-135 \\
\hline Musk ketone ${ }^{93}$ & $\begin{array}{l}\text { River water } \\
(500)\end{array}$ & $\mathrm{C}_{18} /$ manual & SERS & $50-1000$ & $\mathrm{MeOH}(10)$ & $20 / 50$ & 15.2 & $47-63$ \\
\hline Nitroexplosives $^{109}$ & $\begin{array}{l}\text { Plasma and } \\
\text { urine }(0.05) \text {, } \\
\text { water }(0.1)\end{array}$ & $\mathrm{C}_{18} /$ manual & GC-MS & - & $\mathrm{MeOH}(30)$ & $\begin{array}{l}0.014-0.828 / \\
0.046-2.732\end{array}$ & $2.3-4.9$ & $78-99$ \\
\hline \multicolumn{9}{|l|}{ OCPs (organochlorines) } \\
\hline Aldrine, heptachlor, hexachlorobenzene ${ }^{77}$ & Water $(10 \mathrm{ml})$ & $\begin{array}{l}\text { Nano- } \\
\text { diatomite/ } \\
\text { custom }\end{array}$ & GC-MS & $0.1-40$ & DCM (100) & $0.02-0.13 /-$ & $3.5-11.1$ & 78-108 \\
\hline $\begin{array}{l}\text { Alachlor, aldrine, heptachlor, hexachlorobenzene, } \\
\text { metolachlor }^{84}\end{array}$ & $\begin{array}{l}\text { River water } \\
(10 \mathrm{ml})\end{array}$ & CNTs/custom & GC-MS & $0.1-25$ & MIBK (100) & $0.02-0.16 /-$ & $3.3-8.5$ & $81-118$ \\
\hline $\begin{array}{l}\text { Endosulfan isomers and derivatives } \\
\text { ( } \alpha \text {-endosulfan, } \beta \text {-endosulfan, endosulfan ether, } \\
\text { endosulfan lactone, endosulfan sulfate) })^{75}\end{array}$ & Water (750) & $\mathrm{C}_{18} /$ manual & GC-MS & $1-500$ & $\mathrm{MeOH}(30)$ & $\begin{array}{l}0.0038-0.0045 / \\
0.0125-0.035\end{array}$ & $<4.4$ & 88-98 \\
\hline $\begin{array}{l}\text { OPFRs (organophosphate flame retardants) } \\
\text { OPPs (organophosphorus) }\end{array}$ & Water (2 ml) & $\mathrm{SDVB} / \mathrm{eVol}{ }^{\circledR}$ & GC-MS/MS & $0.0027-10$ & $\mathrm{ACN}(3 \times 20)$ & $0.0027-0.107 / 0.01-0.2$ & $<20$ & $69-120$ \\
\hline $\begin{array}{l}\text { Azynphos-ethyl, chlorfenvinfos, chlorpyrifos, } \\
\text { diazinon, parathionethyl, quinalphos }\end{array}$ & $\begin{array}{l}\text { Whole blood } \\
(100)\end{array}$ & $\mathrm{C}_{18} /$ manual & GC-MS/MS & $500-50000$ & $\mathrm{MeOH}(4 \times 110)$ & $-/ 500-2500$ & $<15$ & $61-77$ \\
\hline Diazinon $^{80}$ & Water (2 ml) & $\begin{array}{l}\text { Nanoclay/ } \\
\text { custom }\end{array}$ & CD-IMS & $0.2-20.0$ & $\mathrm{MeOH}(25)$ & $0.07 / 0.20$ & $5-12.3$ & 95-106 \\
\hline
\end{tabular}


Analytical performance

\begin{tabular}{|c|c|c|c|c|c|c|c|c|}
\hline \multirow[b]{2}{*}{ Environmental contaminant classes (analytes) ${ }^{\text {Ref }}$} & \multirow{2}{*}{$\begin{array}{l}\text { Matrix }{ }^{\mathrm{Ref}} \\
\text { (sample } \\
\text { volume, } \mu \mathrm{l} \text { ) }\end{array}$} & \multirow[b]{2}{*}{$\begin{array}{l}\text { MEPS } \\
\text { sorbent/type }\end{array}$} & \\
\hline & & & Methodology & $\begin{array}{l}\text { Linear range } \\
\left(\mathrm{ng} \mathrm{ml}^{-1}\right)\end{array}$ & $\begin{array}{l}\text { Elution } \\
\text { solvent }^{*}(V, \mu \mathrm{l})\end{array}$ & LOD/LOQ (ng ml $\left.{ }^{-1}\right)$ & $\operatorname{RSD}(\%)$ & $\begin{array}{l}\text { Recovery } \\
(\%)\end{array}$ \\
\hline Diazinon, ethion, malathion ${ }^{86}$ & Water $\left(\begin{array}{ll}10 & 000\end{array}\right)$ & $\begin{array}{l}\text { Nano-perlite/ } \\
\text { custom }\end{array}$ & GC-MS & $0.4-35.0$ & DCM (100) & $0.07-0.38 /-$ & $2.8-8.9$ & $81-103$ \\
\hline PAHs (polycyclic aromatic hydrocarbons) ${ }^{88}$ & Water $(4.5 \mathrm{ml})$ & $\mathrm{C}_{8} /$ autosampler & GC-MS & $0.001-1$ & $\mathrm{MeOH}(25 \times 50)$ & $\begin{array}{l}\text { Draw-eject: } \\
0.0005-0.002 / \\
0.0016-0.0062 \\
\text { Extract-discard: } \\
0.0002-0.0008 / \\
0.0008-0.002\end{array}$ & $0.5-14.2$ & $98-122$ \\
\hline PCBs $(28,52,101,118,138,153,181)^{102}$ & $\begin{array}{l}\text { Bovine serum } \\
(100)\end{array}$ & $\mathrm{C}_{8} /$ manual & GC-MS & $2-200$ & EtAc (50) & $0.06-0.53 / 0.20-1.77$ & $<5.72$ & $60-91$ \\
\hline Pyrethroids ${ }^{87}$ & Urine (500) & $\mathrm{C}_{18} / \mathrm{eVol}{ }^{\circledR}$ & LVI-GC-MS & $0.05-25$ & $\begin{array}{l}\text { HFIP/DIC/hex } \\
(1: 2: 97)(2 \times 40)\end{array}$ & $0.06-0.08 /-$ & $<14$ & $92-124$ \\
\hline VOCs $^{99}$ & Water (0.5) & $\begin{array}{l}\mathrm{C}_{18} / \\
\text { autosampler }\end{array}$ & PTV-GC-MS & $0.2-20$ & $\mathrm{ACN}: \mathrm{MeOH}$ & $0.02-1.72 /-$ & $1.5-19.2$ & - \\
\hline $\begin{array}{l}\text { trans, trans-Muconic acid (index for benzene } \\
\text { exposure) }^{110}\end{array}$ & Urine & MIPs/custom & HPLC-UV & $15-2000$ & $\begin{array}{l}\text { EtOH/acetic acid } \\
(80: 20)\end{array}$ & $15 / 50$ & $3.4-6.6$ & 90 \\
\hline
\end{tabular}

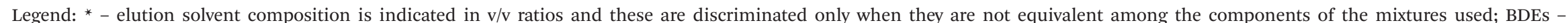

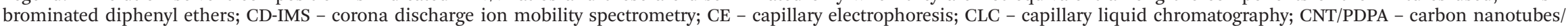

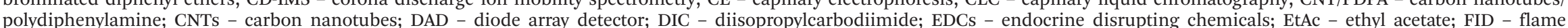

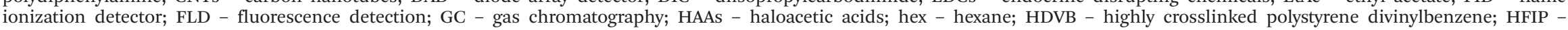

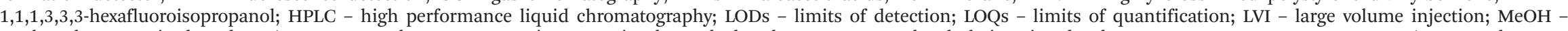

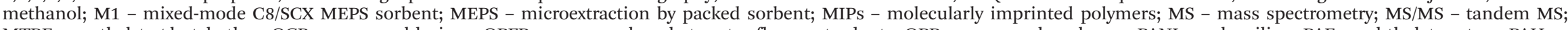

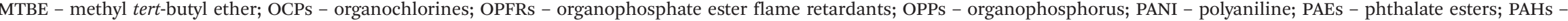

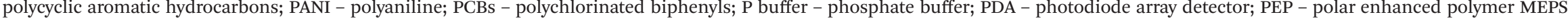

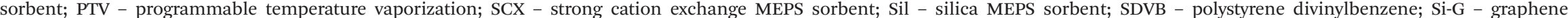
supported on aminopropyl silica; UHPLC - ultra performance liquid chromatography; VOCs - volatile organic compounds; UV - ultraviolet detection. 
carcinogenicity and persistence (highly soluble in water). Dyes, pesticides and pharmaceuticals are obtained using aromatic amines and so these compounds may be released into the environment directly through industrial discharges, or indirectly through the degradation of, for instance, azo dyes and pesticides. ${ }^{95}$ This fact led the EU to classify aromatic amines as priority pollutants that should be monitored regularly in surface waters. ${ }^{95}$ In this context, Sánchez et al. ${ }^{95}$ proposed a MEPS/GC-MS method to assay the water contamination with aromatic amines from azo dyes used in the textile industry. Related with this, Noche et al. ${ }^{96}$ developed a fully automated method based on MEPS-PTV/GC-MS for the determination of chlorobenzene congeners ${ }^{96}$ in water samples. These compounds have been widely used for many decades for industrial and domestic applications (as solvents, degreasing agents and pesticides), but unfortunately they also constitute an important source of environmental contamination. Endocrine Disrupting Chemicals (EDCs) are compounds that mimic human hormones and can block their receptors in our bodies. Depending on the exposition levels, this interference can disrupt the normal activity of the endocrine system leading to its malfunctioning. ${ }^{97}$ Although EDCs are usually found at low concentrations in the aquatic environment, their ability to initiate estrogenic activity even at trace levels led the EU to classify these hormone-like chemicals as hazardous. Thus, their monitorization and control in environmental samples is crucial and for this purpose several analytical methods have been purposed. Among these, Kaur et al. ${ }^{97}$ coupled MEPS with HPLC-UV to detect EDCs (pesticides) in biological and environmental samples. Parabens are esters of $p$-hydroxybenzoic acid widely used as preservatives in foodstuffs, cosmetics and pharmaceutical drugs. Recently, they were proposed as emerging contaminants due to their weak endocrine disrupter potential. ${ }^{98}$ In this context, several MEPS approaches have already been described to extract parabens from environmental waste waters. With this aim, Fumes et al..$^{99}$ proposed a MEPS/HPLC-UV approach using graphene supported on aminopropyl silica through covalent bonds (SiG) as a MEPS sorbent. In turn, Jardim et al. ${ }^{73}$ used the $\mathrm{C}_{18}$ MEPS sorbent combined with UHPLC-MS/MS for the simultaneous determination of five parabens in human urine samples. As by-products of drinking water disinfection, the accumulation of haloacetic acids (HAAs) in the human body is potentially carcinogenic. This has led the USEPA to establish a maximum contamination level (MCL) of $60 \mu \mathrm{g} \mathrm{l} \mathrm{l}^{-1}$ for the sum of HAA concentrations in drinking water. ${ }^{100}$ In this context, Ferreira et al. ${ }^{100}$ proposed a novel analytical method based on in situ aqueous derivatization followed by MEPS/GC-MS for the determination of five HAAs in drinking and swimming pool water. As shown in Table 2, the use of MEPS in environmental analysis is very popular for water matrices, a fact that is certainly related with the low complexity and viscosity of the samples, therefore requiring less processing steps. Nevertheless, there are some interesting applications involving the extraction of different environmental contaminants in more complex samples, as textiles, ${ }^{95}$ soils, ${ }^{101}$ blood, ${ }^{85,97}$ or serum. ${ }^{102}$ There are also several examples reporting MEPS approaches to detect pesticides and other environmental contaminants in food matrices, such as wheat flour, ${ }^{103}$ honey ${ }^{104}$ or corn. ${ }^{105}$ These and other examples will be considered in more detail in the section specifically dedicated to food composition and quality (Table 4).

\section{Forensic analysis and drugs of abuse}

Detection of drugs and related substances may be a very challenging task, requiring highly sensitive and selective analytical techniques. In a forensic context, this is extremely important, since a positive result for the presence of a drug may have legal implications for the examinee's life or freedom. ${ }^{111}$ In this sense, forensic drug chemistry and toxicology have a fundamental role during a criminal investigation. In this context, forensic chemists analyse samples of unknown materials, including powders, liquids and stains, to determine the chemical identity or characteristics of the compounds in the sample. In turn, forensic toxicologists are concerned with the detection and quantification of drugs and other toxic substances in biological specimens to aid medical or legal investigation of death, poisoning and drug use. ${ }^{112,113}$ In both cases, forensic scientists employ a wide variety of analytical tools, ranging from commercial kit-based immunoassays to sophisticated instrumental techniques (e.g. GC-MS, LC-MS/MS, and MALDI-TOF/MS) to detect, identify and quantify the presence of drugs in several types of matrices. ${ }^{114-116}$ MEPS, due to its ability to combine sample extraction, concentration and cleanup in a single device, ${ }^{6}$ reducing the sample volume to the microliter level, gains particular relevance in forensic toxicology. A key reason for this fact is that very often several exams need to be performed on a very limited sample amount and MEPS is particularly tailored to cope with this limitation. ${ }^{117}$ Furthermore, MEPS can be easily combined with chromatographic techniques, such as GC-MS and LC-MS/MS, constituting therefore an excellent tool for the screening and determination of drugs and their metabolites in biological and other complex samples. ${ }^{112}$ A brief literature review on the last five years shows that MEPS has been successfully applied to the extraction of drugs of abuse, such as amphetamines, ${ }^{118}$ cocaine and its metabolites, ${ }^{119}$ opioids, ${ }^{120,121}$ and cannabinoids, ${ }^{120,122}$ as well as several classes of new psychoactive substances, ${ }^{123,124}$ from biological samples. Interestingly, MEPS has also been used to extract benzodiazepines, a class of drugs commonly used in drug-facilitated crimes, from several types of beverages. ${ }^{125,126}$ Table 3 summarizes the most recent applications of MEPS for the determination of drugs and their metabolites in a forensic context. The broad range of applications included in that table clearly reflect the advantages of MEPS and its suitability for toxicology assays. In the analysis of drugs of abuse, silica-based sorbents containing $\mathrm{C}_{18}$ or $\mathrm{C}_{8}$ groups and mixed-mode $\mathrm{C}_{8} / \mathrm{SCX}$ (M1) are the most commonly used sorbents. In general, the versatility of $\mathrm{C}_{8}$ and $\mathrm{C}_{18}$ bonded silica sorbents combines good retention capacity with high recoveries, making these sorbents very attractive for drug analysis. On the other hand, M1 selectivity is more suitable to 


\begin{tabular}{|c|c|c|c|c|c|c|c|c|}
\hline \multirow[b]{2}{*}{ Drug class (analytes) ${ }^{\text {Ref }}$} & \multirow{2}{*}{$\begin{array}{l}\text { Matrix } \\
\text { (sample } \\
\text { volume, } \mu \mathrm{l} \text { ) }\end{array}$} & \multirow{2}{*}{$\begin{array}{l}\text { MEPS } \\
\text { sorbent/ } \\
\text { type }\end{array}$} & \multicolumn{6}{|c|}{ Analytical performance } \\
\hline & & & Methodology & $\begin{array}{l}\text { Linear range } \\
\left(\mathrm{ng} \mathrm{ml}^{-1}\right)\end{array}$ & $\begin{array}{l}\text { Elution solvent* } \\
(V, \mu \mathrm{l})\end{array}$ & $\begin{array}{l}\mathrm{LOD} / \mathrm{LOQ} \\
\left(\mathrm{ng} \mathrm{m} \mathrm{m}^{-1}\right)\end{array}$ & $\begin{array}{l}\text { RSD } \\
(\%)\end{array}$ & $\begin{array}{l}\text { Recovery } \\
(\%)\end{array}$ \\
\hline \multicolumn{9}{|l|}{ Anaesthetics (ANAEs) } \\
\hline Ketamine $^{129}$ & $\begin{array}{l}\text { Fruit juices } \\
(400)\end{array}$ & $\begin{array}{l}\text { M1/ } \\
\text { manual }\end{array}$ & Q-TOF & - & - & $-1-$ & - & - \\
\hline Ketamine, norketamine ${ }^{127}$ & $\begin{array}{l}\text { Plasma, urine } \\
(250)\end{array}$ & $\begin{array}{l}\text { M1/ } \\
\text { manual }\end{array}$ & GC-MS/MS & $\begin{array}{l}10-250 / \\
10-500\end{array}$ & $\mathrm{MeOH}(50)$ & $5 / 10$ & $<15$ & $63-101$ \\
\hline \multicolumn{9}{|l|}{ Benzodiazepines } \\
\hline $\begin{array}{l}\text { Bromazepam, chlordiazepoxide, clobazam, } \\
\text { clonazepam, flunitrazepam, flurazepam, } \\
\text { lorazepam, oxazepam }{ }^{126}\end{array}$ & Beverages (300) & $\mathrm{C}_{18} / \mathrm{eVol}{ }^{\circledR}$ & UHPLC-UV & $2.5-125$ & $\mathrm{ACN}(3 \times 100)$ & $\begin{array}{l}860-1750 / \\
2070-5830\end{array}$ & $<2.78$ & 21-102 \\
\hline $\begin{array}{l}\text { Chlordiazepoxide, diazepam, lorazepam, } \\
\text { medazepam, oxazepam }{ }^{125} \\
\text { Cannabinoids }\end{array}$ & $\begin{array}{l}\text { Grappa drink } \\
(300)\end{array}$ & $\mathrm{C}_{18} / \mathrm{eVol}{ }$ & UHPLC-UV & $1-100$ & $\operatorname{ACN}(3 \times 100)$ & $500 / 2000$ & $<12$ & $61-92$ \\
\hline $\begin{array}{l}\text { 11-Hydroxy-THC, 11-nor-9-carboxy-THC, } \\
\text { cannabidiol, cannabinol, } \text { THC }^{130}\end{array}$ & Oral fluid (125) & $\begin{array}{l}\mathrm{C}_{18} / \\
\text { manual }\end{array}$ & LC-MS/MS & $0.02-1.0$ & MEOH $(2 \times 25)$ & $\begin{array}{l}0.008-0.12 / \\
0.020-0.40\end{array}$ & $<1.16$ & 50-105 \\
\hline 11-Hydroxy-THC, 11-nor-9-carboxy-THC, THC ${ }^{122}$ & Plasma (250) & $\begin{array}{l}\text { M1/ } \\
\text { manual }\end{array}$ & GC-MS/MS & $0.1-30$ & $\begin{array}{l}10 \% \mathrm{NH}_{4} \mathrm{OH} / \mathrm{MeOH} \\
(6 \times 100)\end{array}$ & $1 / 1$ & $<14.25$ & $53-78$ \\
\hline \multicolumn{9}{|l|}{ Cocaine and metabolites (COC) } \\
\hline $\begin{array}{l}\text { Benzoylecgonine, cocaine, ecgonine methyl } \\
\text { ester }{ }^{19} \\
\text { Miscellaneous }\end{array}$ & Urine (200) & $\begin{array}{l}\text { M1/ } \\
\text { manual }\end{array}$ & GC-MS & $25-1000$ & $\begin{array}{l}\mathrm{MeOH}\left(1 \% \mathrm{NH}_{4} \mathrm{OH}\right) \\
(4 \times 100)\end{array}$ & $-/ 25$ & $<11.4$ & $15-83$ \\
\hline $\begin{array}{l}\text { New psychoactive substances (PHEs, PIPs, } \\
\text { SCANs, SCATs) }\end{array}$ & Oral fluid (90) & $\begin{array}{l}\mathrm{C}_{18} / \\
\text { manual }\end{array}$ & $\begin{array}{l}\text { UHPLC-MS/ } \\
\text { MS }\end{array}$ & $0.015-200$ & $\mathrm{MeOH}$ & $\begin{array}{l}0.005-0.850 / \\
0.015-2.600\end{array}$ & $<25$ & $31-96$ \\
\hline Amphetamine (AMPH), methadone (OPI $)^{131}$ & Urine (100) & $\begin{array}{l}\mathrm{C}_{8} / \\
\text { manual }\end{array}$ & MS/MS & $\begin{array}{l}20-5000 \\
5-5000\end{array}$ & $\mathrm{MeOH}(0.1 \% \mathrm{FA})(50)$ & $1.5-6.0 / 5.0-20.0$ & $<17.1$ & $92-107$ \\
\hline $\begin{array}{l}\text { Illicit drugs and metabolites (AMPHs, ANAEs, } \\
\text { COCs, OPIs) }\end{array}$ & Oral fluid (120) & $\begin{array}{l}\mathrm{C}_{18} / \\
\text { manual }\end{array}$ & LC-MS/MS & $0.5-200$ & $\mathrm{MeOH}(5 \mathrm{mM} \mathrm{FA})(5 \times 20)$ & $0.2-10 / 0.5-30$ & $<15$ & $18-102$ \\
\hline Several drugs of abuse (COCs, OPIs, SCATs) $)^{120}$ & Plasma (300) & M1/eVol@ & UHPLC-PDA & $50-10000$ & $\begin{array}{l}\text { DCM }: \text { IPA }: \mathrm{NH}_{4} \mathrm{OH} \\
(78: 20: 2)(200)\end{array}$ & $5-25 / 10-50$ & $<11$ & 80-105 \\
\hline $\begin{array}{l}\text { New psychoactive substances (alkaloids, COCs, } \\
\text { OPIs, SCATs) }\end{array}$ & Oral fluid (300) & $\mathrm{M} 1 / \mathrm{eVol} \circledast$ & $\begin{array}{l}\text { UHPLC-MS/ } \\
\text { MS }\end{array}$ & $0.5-500$ & $\mathrm{DCM} / \mathrm{IPA} / \mathrm{NH}_{4} \mathrm{OH}$ & $-/ 0.5-1.0$ & $<13.7$ & $75-125$ \\
\hline Salvinorin A (Salvia divinorum $)^{132}$ & Urine (200) & $\begin{array}{l}\mathrm{C}_{18} \\
/ \text { manual }\end{array}$ & GC-MS/MS & $20-1000$ & $\mathrm{MeOH}: \mathrm{ACN}(7: 3)(50)$ & $5 / 20$ & $<15$ & $71-80$ \\
\hline
\end{tabular}

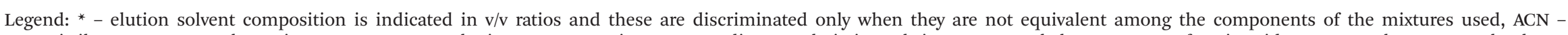

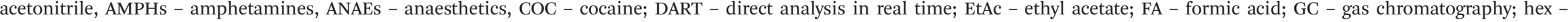

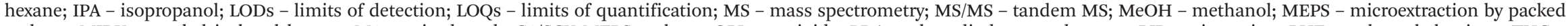

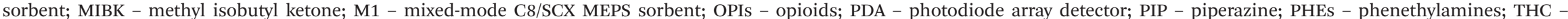

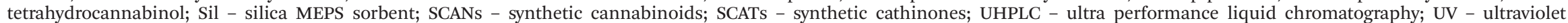
detection. 
extract basic compounds from aqueous solutions, such as drugs and their metabolites from physiological fluids, and for this reason, mixed-mode sorbents have been gaining popularity over the reversed phase sorbents. ${ }^{6}$ Apart from the nature of the sorbent, the nature of the sample matrix has an important influence on MEPS performance. ${ }^{5}$ Generally, biological samples like blood, urine, oral fluid and other complex samples should be processed before being loaded into the MEPS device. ${ }^{5}$ Urine, the most commonly used matrix to assay the presence of drugs of abuse, is typically diluted with deionized water ${ }^{124,127}$ or buffer solutions ${ }^{119}$ prior to the microextraction. Blood and plasma samples are preferential samples to assess the short-term use of drugs of abuse, and the analysis of these specimens by MEPS involves deproteination and dilution of the sample (to reduce the viscosity) before microextraction. Because proteins may cause significant interference, ACN and $\mathrm{MeOH}$ are commonly used to precipitate proteins. ${ }^{120,122}$ Oral fluid has also become a valuable biological specimen for toxicological analysis, particularly in the cases where driving under the influence of drugs is investigated. ${ }^{121}$ Oral fluid provides information on the recent drug use and sample collection is relatively easy and non-invasive, and can be performed under supervision. Nevertheless, some issues, such as varying viscosity, $\mathrm{pH}$, sample availability, and potential external contamination, should be considered. ${ }^{121}$ Often the oral fluid sample is diluted or pre-treated before microextraction to discard potential interferents, such as proteins, food debris and air bubbles. ${ }^{128}$ Eventually, this procedure can affect the analytical performance of the methodology and so, in such cases, the number of extraction cycles can be increased to favour the enrichment of the target analytes. The same strategy is usually applied for plasma or urine samples. Taking into consideration the reports using MEPS for drugs of abuse analysis (Table 3), the number of extraction cycles for plasma samples can vary from 10 up to 26 cycles with sample volumes ranging from 250 to $300 \mu \mathrm{l}$. This high number of aspirations is justified because plasma samples are typically diluted at least 20 times to prevent the obstruction of MEPS cartridges. ${ }^{127}$ For urine samples, the number of extraction cycles is lower, varying from 5 to 8 cycles, with sample volumes ranging from 100 to $200 \mu \mathrm{L}$, while for oral fluid 5 to 6 cycles with a sample volume from 90 to $300 \mu \mathrm{L}$ are enough to achieve the best extraction efficiency. It should be noted that a controlled sample flow, generally between 10 and $20 \mu \mathrm{L} \mathrm{s}^{-1}$, allows a better interaction between the analyte and the sorbent. This feature is obviously more accurate when MEPS is performed using the semiautomatic eVol® syringe, autosamplers or online systems. Finally, it is worthwhile to refer to the applications in which MEPS was directly coupled to the mass detector, therefore greatly simplifying the analytical layout by skipping the chromatographic separation. This approach was applied with success to the detection of the rave drug ketamine in fruit juices. ${ }^{129}$

\section{Food composition}

Over the years, MEPS has been successfully used to extract a wide range of analytes in different biological matrices (such as blood, plasma, urine) and in water (reviewed elsewhere). ${ }^{3,5,9}$ Many of these analytes are the same or very similar to the ones found in foodstuffs and so MEPS was started to be used in food-related applications. Since Anizan (2010) ${ }^{133}$ reported MEPS extraction followed by GC-MS for steroid profiling in cattle (using urine samples), more than 30 studies had been published on the application of MEPS to food matrices. These reports are essentially related with the assessment of food quality under different conditions. The characterization of food composition in bioactive molecules, such as phenolics, ${ }^{134-136}$ is often reported. A second application refers to the evaluation of food integrity by assessing the presence of molecules that result from food contamination, such as pesticides, or degradation, such as compounds resulting from bacterial or fungal spoilage. ${ }^{137-139}$ The excessive usage of veterinary drugs to increase productivity is also studied. ${ }^{102,133,140-143}$ Finally, the presence of contaminants and pesticides in food composition is another very relevant MEPS application (Table 4). ${ }^{78,91,103,105,144,145}$ Regarding this, Capoferri et al. ${ }^{103}$ obtained custom MIPs to use as MEPS sorbents for the extraction of the OPP dimethoate in wheat flour, while Andrade et $a l .{ }^{105}$ used the same strategy to extract the herbicides atrazine, simazine, simetryn, ametryn, and terbutryn in corn samples. More recently, another two custom MEPS sorbents, one obtained with packed hybrids of gold nanoparticles and layered double hydroxide nanosheets $(\mathrm{Au} / \mathrm{LDH}),{ }^{146}$ and the other a metal-organic framework MIL-101(Cr), ${ }^{147}$ were reported to allow even better analytical performance for triazine extraction from maze and corn, respectively. MEPS is often used in the targeted analysis of a limited number of analytes. However, several examples show that this extraction approach is robust enough for multiresidue analysis, as reported by Salami and Queiroz ${ }^{104}$ and Di Ottavio et al. ${ }^{144}$ In these studies, MEPS was used to verify the presence of 22 pesticides in honey ${ }^{104}$ and 25 pesticides and fungicides in wheat flour. ${ }^{144}$ More recently, MEPS is also being used to define signatures to certify the authenticity of certain food products, notably beverages. This is achieved through the comprehensive analysis of their volatile and semi-volatile profiles. ${ }^{148}$ In fact, as shown in Table 4, beverage composition, particularly wine, is a popular MEPS application. As already mentioned, this trend is easily understood, as the matrix is already in the liquid form, therefore facilitating the extraction of the target analytes with minimum sample pre-treatment. Another interesting MEPS application in food research relates with the assessment of food intake through the analysis of the presence of different dietary metabolites in plasma and urine. This is particularly relevant to show the internalization of certain antioxidants to plasma, namely phenolic compounds, following the ingestion of different foodstuffs rich in these compounds, often known as functional foods. This has been elegantly used to find the presence of olive biophenols, caffeic acid, oleuropein and tyrsol, in rat plasma following the ingestion of olive oil. ${ }^{149}$ To perform this assay the authors developed a new MEPS sorbent, a carbon nanoporous adsorbent (CMK-3), and the extraction was followed by a LC-UV analysis. A similar assay was performed 
Analytical performance

\begin{tabular}{|c|c|c|c|c|c|c|c|c|}
\hline \multirow[b]{2}{*}{ Target analytes (foodstuff) ${ }^{\text {Ref }}$} & \multirow[b]{2}{*}{$\begin{array}{l}\text { Matrix (sample } \\
\text { volume, } \mu \mathrm{l})\end{array}$} & \multirow[b]{2}{*}{ MEPS sorbent/type } & \\
\hline & & & Methodology & 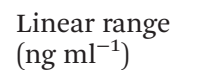 & $\begin{array}{l}\text { Elution solvent* } \\
(V, \mu \mathrm{l})\end{array}$ & $\begin{array}{l}\mathrm{LOD} / \mathrm{LOQ} \\
\left(\mathrm{ng} \mathrm{ml} \mathrm{m}^{-1}\right)\end{array}$ & $\operatorname{RSD}(\%)$ & $\begin{array}{l}\text { Recovery } \\
(\%)\end{array}$ \\
\hline \multicolumn{9}{|l|}{ Food composition } \\
\hline \multirow{2}{*}{$\begin{array}{l}\text { 5-Hydroxymethyl-2-furaldehyde, } \\
\text { 2-furaldehyde, 2-furylmethanol, } \\
\text { 2-furyl methyl ketone and 5-methyl- } \\
\text { 2-furaldehyde }\end{array}$} & \multirow{2}{*}{$\begin{array}{l}\text { Sugarcane honey } \\
(1.5 \mathrm{ml})\end{array}$} & \multirow{2}{*}{$\begin{array}{l}\mathrm{C}_{2}, \mathrm{C}_{8}, \mathrm{C}_{18}, \mathrm{M} 1, \mathrm{PEP}, \\
\text { PGC, RAX, RCX, Sil/ } \\
\text { eVol }{ }^{8}\end{array}$} & \multirow[t]{2}{*}{ UHPLC-PDA } & \multirow[t]{2}{*}{$100-17800$} & \multirow[t]{2}{*}{$\mathrm{ACN}(3 \times 500)$} & $10.1-234.4 /$ & \multirow[t]{2}{*}{$2.1-5.6$} & \multirow[t]{2}{*}{92} \\
\hline & & & & & & $30.6-737.7$ & & \\
\hline $\begin{array}{l}\text { 5-Hydroxymethyl-2-furaldehyde, } \\
\text { 5-methyl-2-furaldehyde, }\end{array}$ & Madeira wine (600) & $\mathrm{C}_{2}, \mathrm{C}_{8}, \mathrm{C}_{18}, \mathrm{M} 1, \mathrm{PGC}$, & UHPLC-PDA & $40-700000$ & 95\% $\mathrm{MeOH}(200)$ & $0.0045-0.1293 /$ & - & 74 \\
\hline \multicolumn{9}{|l|}{$\begin{array}{l}\text { 2-furaldehyde and } 2 \text {-furylmethyl } \\
\text { ketone }^{152}\end{array}$} \\
\hline \multicolumn{2}{|l|}{$\begin{array}{l}\text { 2-furfural, furyl methyl ketone and } \\
\text { 5-methyl-2-furfural }{ }^{153}\end{array}$} & $\mathrm{C}_{8} / \mathrm{eVol}{ }^{\circledR}$ & UHPLC-PDA & - & $\mathrm{MeOH}(200)$ & $-1-$ & - & - \\
\hline Bioactive phenolic compounds ${ }^{134}$ & $\begin{array}{l}\text { Methanolic extract } \\
\text { of argan leaves } \\
(100)\end{array}$ & $\begin{array}{l}\mathrm{C}_{2}, \mathrm{C}_{8}, \mathrm{C}_{18}, \mathrm{M1} / \\
\mathrm{eVol} \AA\end{array}$ & LC-DAD-MS/MS & $0.3-100$ & $\mathrm{MeOH}(500)$ & $0.3 / 0.1$ & $<3.7$ & 87 \\
\hline $\begin{array}{l}\text { Isoanthohumol and } \\
\text { xanthohumol }^{135}\end{array}$ & Beers $(500)$ & $\begin{array}{l}\mathrm{C}_{2}, \mathrm{C}_{8}, \mathrm{C}_{\mathbf{1 8}}, \mathrm{M} 1, \mathrm{Sil} / \\
\mathrm{eVol} \circledast\end{array}$ & UHPLC-PDA & $1-5000$ & $\operatorname{ACN}(250)$ & $0.4-1.0 / 0.9-3.0$ & $0.4-1.6$ & 67 \\
\hline $\begin{array}{l}\text { xanthohumol } \\
\text { Ellagic acid }\end{array}$ & $\begin{array}{l}\text { Pomegranate and } \\
\text { grape juice }(2.5 \mathrm{ml})\end{array}$ & $\begin{array}{l}\text { Functionalized } \mathrm{SB}_{\mathrm{A}^{-}} \\
15 / \text { custom }\end{array}$ & HPLC-UV & $500-100000$ & $\operatorname{ACN}(6 \times 80)$ & $0.8 /-$ & - & 97 \\
\hline $\begin{array}{l}\text { Hydrocarbon, ester, alcohol and } \\
\text { fatty acid (Solanaceous plant } \\
\text { species) }\end{array}$ & $\begin{array}{l}\text { Solanaceous plant } \\
\text { cuticular waxes }(50)\end{array}$ & Sil/eVol® & $\begin{array}{l}\text { GC-FID } \\
\text { GC-MS }\end{array}$ & - & $\begin{array}{l}\text { Petroleum ether } \\
\text { (50); DCM:15\% } \\
\text { acetone }(2 \times 50)\end{array}$ & $-1-$ & - & - \\
\hline $\begin{array}{l}\text { Senkyunolide A and ligustilide } \\
\text { (bioactive compounds) }^{155}\end{array}$ & Rhizoma chuanxiong & $\mathrm{C}_{18} /$ manual & $\begin{array}{l}\text { VSMC/ } \\
\text { CMC-MEPS-GC-MS }\end{array}$ & $250-4000$ & $\mathrm{MeOH}(1 \mathrm{ml})$ & $-1-$ & - & - \\
\hline $\begin{array}{l}\text { Volatile profile (multi-VOC } \\
\text { analysis) }\end{array}$ & $\begin{array}{l}\text { "Sweet" and "hard" } \\
\text { ciders }(500)\end{array}$ & $\mathrm{C}_{18} /$ manual & GC-MS and GC-FID & $40-300000$ & DCM (25) & $\begin{array}{l}0.02-2.34 / \\
0.04-4.69\end{array}$ & $1.9-5.9$ & - \\
\hline \multicolumn{9}{|l|}{ Food quality markers } \\
\hline \multirow{2}{*}{$\begin{array}{l}\text { Benzylbutyl phthalate, dibutyl } \\
\text { phthalate, dicyclohexyl phthalate, } \\
\text { diethyl phthalate and dipropyl } \\
\text { phthalate }^{91} \\
\text { Ethyl carbamate }^{137}\end{array}$} & $\begin{array}{l}\text { Carbonated drinks, } \\
\text { perfumes and } \\
\text { creams (500) }\end{array}$ & $\mathrm{C}_{18} /$ manual & GC-MS & $0.5-500$ & $\mathrm{MeOH}(30)$ & $\begin{array}{l}0.003-0.015 / \\
0.009-0.049\end{array}$ & $1.3-2.7$ & 88 \\
\hline & Madeira wine (300) & $\begin{array}{l}\mathrm{C}_{2}, \mathrm{C}_{8}, \mathrm{C}_{18}, \mathrm{M} 1, \mathrm{Sil} / \\
\mathrm{eVol} \circledast\end{array}$ & GC-MS & $5-400$ & DCM (100) & $1.5 / 4.5$ & $5.0-7.0$ & 97 \\
\hline Ochratoxin A (OTA) $)^{138}$ & $\begin{array}{l}\text { Red, white and rosé } \\
\text { wines (350) }\end{array}$ & $\mathrm{C}_{18} / \mathrm{eVol}{ }^{\circledR}$ & HPLC-FLD & $0.02-3.0$ & $\begin{array}{l}\text { ACN : } 0.2 \% \text { Acetic } \\
\text { acid }(90: 10)(2 \times \\
25)\end{array}$ & $0.08 / 0.24$ & $3.8-4.5$ & 90 \\
\hline Sotolon $^{139}$ & $\begin{array}{l}\text { Red, white and } \\
\text { fortified wine ( } 750)\end{array}$ & $\begin{array}{l}\mathrm{C}_{2}, \mathrm{C}_{8}, \mathrm{C}_{18}, \mathrm{M} 1, \text { PEP, } \\
\text { PGC, RAX, RCX, Sil/ } \\
\text { eVol® }\end{array}$ & UHPLC-PDA & $10000-100000$ & $50 \% \mathrm{MeOH}(100)$ & $\begin{array}{l}0.45-2.51 / \\
1.49-8.36\end{array}$ & $0.4-5.6$ & 81 \\
\hline Dietary compounds & & & & & & & & \\
\hline $\begin{array}{l}\text { Olive biophenols (caffeic acid, } \\
\text { oleuropein, tyrsol) }\end{array}$ & Plasma (200) & CMK-3/eVol@ & HPLC-UV/VIS & $0.005-2$ & $\operatorname{ACN}(100)$ & $\begin{array}{l}0.25-4.7(\mu \mathrm{M}) / \\
0.82-15.7(\mu \mathrm{M})\end{array}$ & $<2.5$ & $84-106$ \\
\hline Diet-derived phenolic acids ${ }^{150}$ & Plasma & $\mathbf{C}_{\mathbf{1 8}}$ /online & GC-MS/MS & - & $\operatorname{ACN}(360)$ & $-1-$ & $>15$ & $10-120$ \\
\hline Environmental contaminants ( & & & & & & & & \\
\hline $\begin{array}{l}\text { Ametryn, atrazine, bifenthrin, } \\
\text { carbofuran, metribuzine, }\end{array}$ & Sugarcane (250) & $\mathrm{C}_{18} /$ manual & GC-MS & $2.0-1000$ & EtAc (30) & $0.2-1.5 / 2-10$ & $3.9-15.9$ & $72-107$ \\
\hline
\end{tabular}


Analytical performance

\begin{tabular}{|c|c|c|c|c|c|c|c|c|}
\hline Target analytes (foodstuff) ${ }^{\text {Ref }}$ & $\begin{array}{l}\text { Matrix (sample } \\
\text { volume, } \mu \mathrm{l})\end{array}$ & MEPS sorbent/type & Methodology & 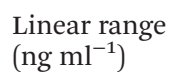 & $\begin{array}{l}\text { Elution solvent* } \\
(V, \mu \mathrm{l})\end{array}$ & $\begin{array}{l}\text { LOD/LOQ } \\
\left(\mathrm{ng} \mathrm{ml}^{-1}\right)\end{array}$ & RSD (\%) & $\begin{array}{l}\text { Recovery } \\
(\%)\end{array}$ \\
\hline $\begin{array}{l}\text { Ametryn, atrazine, simazine, } \\
\text { simetryn, terbutryn }{ }^{105}\end{array}$ & Corn (1000) & MIPs/manual & LC-ESI-ToF & $10-80$ & $\begin{array}{l}\text { ACN : } 0.1 \% \text { acetic } \\
\text { acid }(70: 30)(1 \mathrm{ml})\end{array}$ & $3.3 / 10\left(\mathrm{ng} \mathrm{g}^{-1}\right)$ & $0.4-12.1$ & 92-102 \\
\hline Clofentezine ${ }^{145}$ & $\begin{array}{l}\text { Milk and juice } \\
\text { samples }\end{array}$ & $\begin{array}{l}\text { Polythiophene } \\
\text { dendrimer/custom }\end{array}$ & HPLC-UV & $1-10000$ & $\mathrm{MeOH}(400)$ & $0.2 /-$ & $5-9.2$ & $93-98$ \\
\hline Dimethoate $^{103}$ & Wheat flour (250) & MIPs/manual & UHPLC-MS/MS & $22.9-229.3$ & $\mathrm{ACN}(3 \times 100)$ & $-1-$ & $0.7-2.7$ & 60 \\
\hline $\begin{array}{l}\text { Pesticides (multiresidue } \\
\text { analysis) }\end{array}$ & Honey (3 g) & $\begin{array}{l}\mathrm{C}_{8}, \text { M1, SAX, SCX, } \\
\text { Sil/manual }\end{array}$ & GC-MS & $2-100$ & EtAc (20) & $-/ 10\left(\operatorname{ng}^{-1}\right)$ & $2.0-15.0$ & $82-114$ \\
\hline $\begin{array}{l}\text { Pesticides and fungicides } \\
\text { (multiresidue analysis) }^{144}\end{array}$ & Wheat flour (250) & $\mathrm{HDVB} / \mathrm{manual}$ & UHPLC-MS/MS & $0.0001-250$ & $\operatorname{ACN}(3 \times 100)$ & $\begin{array}{l}0.30-5.00 / \\
0.75-15.00\end{array}$ & $2.0-13.0$ & 19-98 \\
\hline Triazine herbicides & $\begin{array}{l}\text { Maize }{ }^{146} \\
\text { Corn }^{147}\end{array}$ & $\begin{array}{l}\mathrm{Au} / \mathrm{LDH} / \text { custom } \\
\mathrm{MIL}-101(\mathrm{Cr}) / \text { custom }\end{array}$ & $\begin{array}{l}\text { HPLC-DAD } \\
\text { HPLC-MS }\end{array}$ & $\begin{array}{l}2.5-300 \\
2.0-200\end{array}$ & $\begin{array}{l}\text { EtAc }(400) \\
\text { ACN }(2 \mathrm{ml})\end{array}$ & $\begin{array}{l}35-108\left(\mathrm{pg} \mathrm{g}^{-1}\right) \\
0.01-0.12 / \\
0.04-0.35(\mathrm{ng} \\
\left.\mathrm{g}^{-1}\right)\end{array}$ & $\begin{array}{l}0.99-2.88 \\
<9.11\end{array}$ & - \\
\hline $\begin{array}{l}\text { Veterinary drug usage } \\
\text { Polychlorinated biphenyls }(28,52 \text {, } \\
101,118,138,153 \text { and } 180)^{102}\end{array}$ & Bovine serum (100) & $\mathrm{C}_{18} /$ custom & GC-MS & $2-200$ & EtAc $(2 \times 50)$ & $\begin{array}{l}0.06-0.53 / \\
0.20-1.77\end{array}$ & $1.90-5.66$ & 60 \\
\hline Ractopamine $^{141}$ & $\begin{array}{l}\text { Porcine muscle and } \\
\text { urine (1000) }\end{array}$ & $\mathbf{C}_{18}, \mathbf{M 1} / \mathrm{eVol} \circledast$ & HPLC-UV & $0.01-2$ & $\begin{array}{l}95 \% \mathrm{MeOH}: 0.2 \% \\
\mathrm{NH}_{4} \mathrm{OH}(300)\end{array}$ & $0.003 / 0.010$ & $3.9-7.6$ & 82 \\
\hline Tetracycline residues ${ }^{143}$ & Milk & Graphene/custom & UHPLC-MS/MS & $15-110$ & $\mathrm{MeOH}(100)$ & $-/ 50-900$ & $2.1-8.8$ & $87-118$ \\
\hline
\end{tabular}

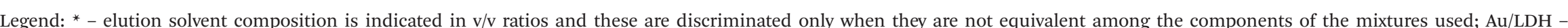

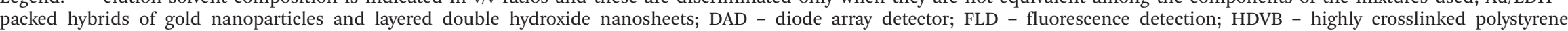

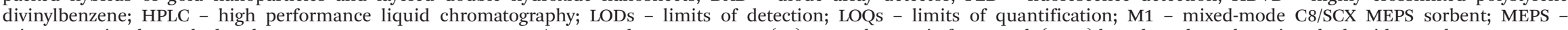

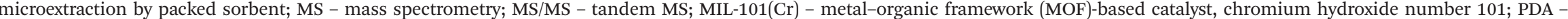

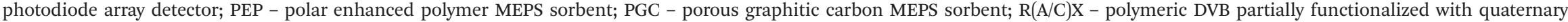

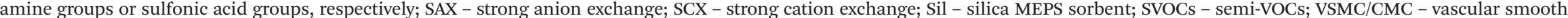
muscle cells/cell membrane chromatography; UHPLC - ultra high performance liquid chromatography; UV - ultraviolet detection; $\mu \mathrm{ECD}$ - microelectron-capture detector. 
with gerbil (desert rats) fed with calafate, an edible Patagonian dark blue berry rich in phenolic acids. ${ }^{150}$ In this case, however, the authors used a MEPS-GC-MS/MS experimental layout to screen 40 dietary phenolics previously derivatized. This strategy aimed to obtain the complete metabolic snapshot that follows the ingestion of calafate extract by mammals.

\section{Comparison with other microextraction techniques}

In the sample preparation procedure, the extraction step has a critical influence on the analytical performance of the methodology proposed to analyse a given analyte. The conventional extraction approaches, such as liquid-liquid extraction (LLE) and solid phase extraction (SPE) showed good responses for a large number of target analytes in different sample matrices. . $^{26,107,128,156,157}$ However, the traditional extraction techniques are mostly time consuming and require large amounts of organic solvents and samples. ${ }^{86,107,156,157}$ To minimize these drawbacks, different strategies have been proposed, such as the use of ultrasound in the sample processing and extraction steps, ${ }^{80,92,107,126}$ or different forms of conventional LLE and SPE miniaturization. ${ }^{126,156,158,159}$ In terms of liquidliquid microextraction (LLME), methodologies like SDME (single drop microextraction) $)^{158-160}$ or DLLME (dispersive liquid-liquid microextraction) $)^{126,161,162}$ have been reported as good alternatives to the traditional protocols, presenting several advantages, such as a drastic solvent reduction and a great preconcentration factor. ${ }^{126,158-162}$ Nevertheless, such approaches involve experimental protocols and manipulation of the extraction devices that require some specific skills. ${ }^{163}$ In contrast, the microextraction approaches involving SPE miniaturization are more simple and prone to automation, while also allowing a significant solvent and sample reduction. In this context, several methodologies, such as SPME, ${ }^{164-166}$ SBSE, ${ }^{167,168}$ and MEPS ${ }^{2,80,107,157}$ have been widely reported in the literature for the extraction of a great range of analytes in different fields of application. Several of these reports included extensive comparisons with the literature about MEPS efficiency against other extraction approaches for the same target analytes. This is the case of the initial work of AbdelRehim, ${ }^{1}$ reported in 2004, that clearly pointed that MEPS allows similar or better extraction efficiency than conventional methodologies for the extraction of several anaesthetics. ${ }^{1}$ This was also previously shown for different antiepileptic drugs, ${ }^{169,170}$ or NSAIDs. ${ }^{171}$ In this section, however, we will mainly focus on the comparisons in recent reports involving microextraction techniques, such as DLLME, ${ }^{126,172,173}$ HF-LPME ${ }^{87,100} \quad \mathrm{SDME}^{109,174} \quad \mathrm{SPE}^{175-180}$ and SPME, ${ }^{1,109,133,181,182}$ that already incorporate significant technological improvements by comparison with more conventional techniques, such as $\operatorname{LLE}^{1,87,183}$ and SPE (Table 5). ${ }^{1,87,109,120,183}$ These comparisons of MEPS applications with other extraction approaches would be more meaningful if the same experimental conditions were involved but unfortunately this is not available so far for many applications. Apart from small variations in the experimental protocols used, often the matrices used were not the same, nor the ana- lysis that followed the extraction procedure. Therefore, the comparison between different extraction approaches for the same target analytes was simplified to the analytical performance level (limits of detection and quantification, precision and recovery). Accordingly, the examples shown in Table 5 involve target analytes from different applications including several classes of pharmaceutical drugs, drugs of abuse, pesticides, environmental contaminants and bioactive compounds. Overall, it is shown that the analytical performance obtained with MEPS is, at least, in the same range as other methodologies reported in the literature. This certainly makes the adoption of this approach more advantageous at different levels, as previously demonstrated. There are, nevertheless, some examples whose performance may be more interesting in favour of other extraction approaches. Sánchez et al. ${ }^{95}$ for instance, compared the extraction efficiency of MEPS (using the HyperSep ${ }^{\mathrm{TM}}$ Retain ${ }^{\mathrm{TM}}$ PEP sorbent) with salting-outassisted liquid-liquid extraction (SALLE), both combined with GC-MS for the determination of aromatic amines formed from azo dyes in textiles. Based on the results obtained, low LODs and less interfering compounds from the matrix were achieved using MEPS, whereas SALLE showed the highest recovery rates and lower time for extraction and preconcentration of the target analytes. Regarding the analytical performance, good results were achieved for all target analytes, in terms of linearity, LOD and recovery. NSAIDs are pain-relieving therapeutic agents widely used in the human population. Their administration is so massive that there are growing concerns about the side effects of NSAIDs on human health, as well as on the environment. ${ }^{184}$ Therefore, there are abundant reports in the literature involving different methodologies to quantify NSAIDs in biofluids (mainly plasma and urine) and environmental waters. Table 5 presents a comparative analysis of MEPS and SPE extractions followed by liquid chromatographic separation. As can be observed, MEPS extraction using commercial $\mathrm{C}_{18}$ sorbents $^{25,46-48}$ retrieves equivalent analytical performance to SPE approaches using custom MIP sorbents. ${ }^{185}$ Moreover, both approaches are compatible with the less expensive DAD detection for the quantification of NSAIDs in the biological fluids. This makes MEPS a suitable approach for the extraction of NSAIDs from biological fluids and eventually to monitor the presence of these drug residues in the environment. In this last case, however, the use of MS/MS detection will be necessary to attain the required analytical performance of such analysis.

\section{Innovative improvements and future applications}

Since its introduction by Abdel-Rehim, in 2004, ${ }^{1}$ MEPS has gone through several improvements mainly affecting its technical configuration and sorbents. These were made commercially available for MEPS by simple downscale of the SPE equivalents commercially available, firstly the silica-based sorbents and later the polymeric versions. As already mentioned, a review of the chemistries and properties of the different sorbents com- 
Table 5 Comparison between MEPS and other extraction methods

\begin{tabular}{|c|c|c|c|c|c|c|c|c|}
\hline \multirow[b]{2}{*}{ Class (analytes) (Ref } & \multirow[b]{2}{*}{ Sample matrix } & \multicolumn{2}{|l|}{ Methodology } & \multicolumn{5}{|c|}{ Analytical performance } \\
\hline & & $\begin{array}{l}\text { Extraction } \\
\text { (sample } \\
\text { volume, } \mu \mathrm{L})\end{array}$ & Analysis & $\begin{array}{l}\text { Linear range } \\
\left(\mathrm{ng} \mathrm{ml}^{-1}\right)\end{array}$ & $\begin{array}{l}\text { Elution solvent* } \\
(V, \mu \mathrm{l})\end{array}$ & $\begin{array}{l}\mathrm{LOD} / \mathrm{LOQ} \\
\left(\mathrm{ng} \mathrm{ml}^{-1}\right)\end{array}$ & RSD (\%) & $\begin{array}{l}\text { Recovery } \\
(\%)\end{array}$ \\
\hline \multicolumn{9}{|l|}{ Antibiotics } \\
\hline Levofloxacin, linezolid and meropenem ${ }^{186}$ & Human plasma & MEPS & HPLC-PDA & $10-30000$ & MeOH (150) & $4.0-7.0 / 10-20$ & $<10.5 /<10.8$ & 92-97 \\
\hline $\begin{array}{l}\text { Cefepime, ciprofloxacin, linezolid, } \\
\text { meropenem, moxifloxacin and piperacillin }{ }^{187}\end{array}$ & Human plasma & $\mathrm{PP}$ & HPLC-MS/MS & $50-4000000$ & - & $50-500$ & $<6.8 /<10.9$ & - \\
\hline $\begin{array}{l}\text { Ofloxacin (FLQs) } \\
\text { Antidepressants }\end{array}$ & Urine, plasma & UA-dM- $\mu \mathrm{SPE}$ & Spectrofluorimetry & $1-500$ & - & $0.21 /-$ & $<2.5$ & 98-101.5 \\
\hline $\begin{array}{l}\text { Citalopram, fluoxetine, } \\
\text { paroxetine and sertraline }^{53}\end{array}$ & Human plasma & $\begin{array}{l}\text { MEPS (400) } \\
\text { SBSE (800) }\end{array}$ & $\begin{array}{l}\text { NACE } \\
\text { NACE }\end{array}$ & $10-500$ & 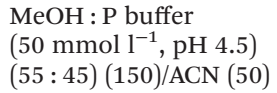 & $\begin{array}{l}-/ 20-30 \\
-/ 10-25\end{array}$ & $\begin{array}{l}-/ 2.9-8.7 \\
-/ 2.9-12.6\end{array}$ & $\begin{array}{l}92-101 \\
95-101\end{array}$ \\
\hline Citalopram and sertraline ${ }^{176}$ & Urine, plasma & $\mathrm{dM}-\mu \mathrm{SPE}$ & HPLC-UV & $2-800$ & $\mathrm{MeOH}$ & $0.6-0.7 / 2$ & $<9.2$ & 94-96.4 \\
\hline Aromatic amines $^{95}$ & $\begin{array}{l}\text { Environmental } \\
\text { water samples }\end{array}$ & $\begin{array}{l}\text { MEPS } \\
\text { SALLE }\end{array}$ & GC-MS & $0.040-989$ & $\begin{array}{l}\text { 1-Propanol }(60) / \\
\text { EtAc (750) }\end{array}$ & $\begin{array}{l}0.040-42 / 0.13-139 \\
0.10-3.7 / 0.35-12\end{array}$ & $\begin{array}{l}-/<15 \\
-/<11\end{array}$ & $\begin{array}{l}1-96 \\
26-98\end{array}$ \\
\hline Antipsychotics (ziprasidone) ${ }^{63}$ & Human plasma & MEPS (100) & HPLC-UV & $1-500$ & $\mathrm{MeOH}(500)$ & $0.3 / 1.0$ & $\begin{array}{l}3.0-3.1 / \\
3.3-4.0 \\
3.2-3.5 / \\
3.7-4.4\end{array}$ & $92-95$ \\
\hline \multirow{3}{*}{$\begin{array}{l}\text { Bromazepam, chlordiazepoxide, clobazam, } \\
\text { clonazepam, flurazepam, flunitrazepam, } \\
\text { lorazepam, oxazepam }{ }^{126}\end{array}$} & Beverages & MEPS (300) & HPLC-UV & $2500-250000$ & $\begin{array}{l}\text { ACN : FA }(90: 10) \\
(3 \times 100)\end{array}$ & $\begin{array}{l}1050-1660 / \\
2070-5530\end{array}$ & $\begin{array}{l}0.14-3.43 / \\
0.78-2.78\end{array}$ & $14-103$ \\
\hline & & DLLME (1000) & & & - & $860-1750 / 2180-5830$ & $\begin{array}{l}0.88-5.82 / \\
1.02-4.21\end{array}$ & $38-102$ \\
\hline & & $\begin{array}{l}\text { UA-DLLME } \\
(1000)\end{array}$ & & & - & - & $\begin{array}{l}0.55-2.27 / \\
0.53-2.02\end{array}$ & $24-102$ \\
\hline $\begin{array}{l}\text { Chlordiazepoxide, diazepam, } \\
\text { lorazepam, medazepam, oxazepam }{ }^{125}\end{array}$ & $\begin{array}{l}\text { Alcoholic } \\
\text { grappa } \\
\text { drink }\end{array}$ & MEPS (300) & UHPLC-UV & $500-2000$ & $\begin{array}{l}\text { ACN : FA }(90: 10) \\
(3 \times 100)\end{array}$ & $500 / 2000$ & $0.5-12 / 1.1-200$ & $61-92$ \\
\hline \multirow[t]{7}{*}{ Chlorobenzene derivatives } & $\begin{array}{l}\text { Water } \\
\text { samples }\end{array}$ & MEPS (1750) & PTV-GC-MS & $\begin{array}{l}0.0003-500 \\
\text { (MEPS) }\end{array}$ & Hex/acetone (25) & $\begin{array}{l}0.0003-0.07 / \\
0.001-0.2\end{array}$ & $\begin{array}{l}2.4-8.0 / \\
2.8-12.0\end{array}$ & $26-81$ \\
\hline & & LLE (500) & GC-MS & - & - & $0.000005-0.00001 /-$ & $-1-$ & $39-73$ \\
\hline & & SPE (200) & GC-MS & & & $0.010-0.045 /-$ & $1.6-13.3 /-$ & $62-98$ \\
\hline & & SPME (5000) & GC-MS & & & $0.003-0.006 /-$ & $1.2-8.2 /-$ & 92-108 \\
\hline & & LPME (4000) & GC-MS & & & $0.020-0.050 /-$ & $1.6-17.9 /-$ & $83-105$ \\
\hline & & SDME $(10000)$ & GC-MS & & & $0.003-0.031 /-$ & $2.1-13.2 /-$ & $82-107$ \\
\hline & $\begin{array}{l}\text { Water } \\
\text { samples }{ }^{174}\end{array}$ & $\begin{array}{l}\text { MHS-SDME } \\
(20000)\end{array}$ & GC-MS & $0.05-5$ & - & $0.004-0.008 /-$ & $3-18 /-$ & $82-114$ \\
\hline \multicolumn{9}{|l|}{ Drugs of abuse } \\
\hline \multirow[t]{2}{*}{$\begin{array}{l}\text { SCATs and other drugs of } \\
\text { abuse and metabolites }{ }^{120}\end{array}$} & Human plasma & MEPS (200) & UHPLC-PDA & $50-10000$ & $\begin{array}{l}\text { DCM }: \text { IPA }: \mathrm{NH}_{4} \mathrm{OH} \\
(78: 20: 2)(200)\end{array}$ & $10-25 / 10-50$ & $\begin{array}{l}0.9-13.8 / \\
1.2-13.8\end{array}$ & $80-105$ \\
\hline & Whole blood & $\begin{array}{l}\text { SPE }(1000) \\
\mu \text { SPE }(100)\end{array}$ & $\begin{array}{l}\text { UHPLC-PDA } \\
\text { LC-MS/MS }\end{array}$ & - & & $\begin{array}{l}-/- \\
-/ 0.25-5\end{array}$ & $-1-$ & $\overline{21-70}$ \\
\hline \multirow{2}{*}{$\begin{array}{l}\text { SCAN, SCAT and PHEs }{ }^{177} \\
\text { Antivirals (entecavir) }\end{array}$} & Plasma & MEPS (50) & UHPLC-MS/MS & $0.5-100$ & $\begin{array}{l}\mathrm{ACN}: 5 \mathrm{mM} \\
\mathrm{NH}_{4} \mathrm{CH} 3 \mathrm{COOH} \\
\mathrm{pH} 4.0(75: 25)(100)\end{array}$ & $0.15 / 0.50$ & $\begin{array}{l}0.9-3.6 / \\
2.9-17.4\end{array}$ & $95-106$ \\
\hline & & PP-SPE (500) & UHPLC-MS/MS & - & $\begin{array}{l}\text { ACN: } 5 \% \mathrm{NH}_{4} \mathrm{OH} \\
(95: 5)(1000)\end{array}$ & $0.3 / 1$ & $\begin{array}{l}1.1-4.1 / \\
2.3-6.3\end{array}$ & $80-106$ \\
\hline
\end{tabular}


Class (analytes) ${ }^{\text {Ref }}$

\section{Haloacetic acids}

(dibromoacetic acid,

dichloroacetic acid,

monobromoacetic acid,

monochloroacetic acid,

trichloroacetic acid)

\section{Nitroexplosives $(2,4,6$}

trinitrophenyl- $N$-methyl-

nitramine; 2,4,6- trinitrotoluen

and its metabolites) ${ }^{10}$

NSAIDs (non-steroidal anti-inflammatory drugs)

Acetylsalicylic acid, diclofenac,

ibuprofen, ketoprofen, naproxen ${ }^{46}$

Fenbufen, flurbiprofen, furprofen,

ibuprofen, indomethacin,

indoprofen, ketoprofen ${ }^{47}$

Carprofen, fenbufen, flurbiprofen,

ibuprofen, indomethacin,

indoprofen and ketoprofen ${ }^{48}$

Several NSAIDs (7) and FLQs $(4)^{2.5}$

Diclofenac, ibuprofen, ketoprofen and naproxen ${ }^{18}$

Ibuprofen, diclofenac ketoprofen

Ibuprofen, diclofenac, ketoprofe

and mefenamic acid ${ }^{179}$

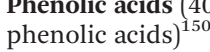

Pyrethroid metabolites $^{87 \%}$

Methodology

\section{Extraction}

(sample

Sample matrix

Tap water and MEPS (2500) swimming pool HF-LPME

$(10 \mathrm{ml})$

HS $(25 \mathrm{ml})$ GC-ECD

SBME (1000)

HS-SPME

$(10 \mathrm{ml})$

Swimming pool $\mu \mathrm{SPE}$

water $^{178}$

Environmental MEPS (50)

(river water)

and

biological

MEPS

SPME

SPE $(25-35 \mathrm{ml})$

SPME $(20 \mathrm{ml})$

urine)

SPME $(5 \mathrm{ml})$

GC-MS

SDME $(5 \mathrm{ml}) \quad$ GC-MS

Urine

MEPS (20)

HPLC-PDA

Plasma, urine

MEPS (85)

HPLC-PDA

Human
dialysates

SPES

MEPS

HPLC-PDA

UHPLC-DAD

Linear range

Elution solvent*

LOD/LOQ
$\left(\mathrm{ng} \mathrm{ml}^{-1}\right)$

RSD (\%) $\quad \begin{aligned} & \text { Recovery } \\ & (\%)\end{aligned}$

$\left(\mathrm{ng} \mathrm{ml}^{-1}\right) \quad(\mathrm{l})$

MTBE (20)

$0.36-1.2 / 1.2-$

$\begin{array}{ll}4.2-9.8 / 9.4-14 & 83-117 \\ 5.0-12.0 /- & 97-109\end{array}$

Urin

MEPS (180)

UHPLC-PDA

Urine

MIP-SPE

UHPLC-DAD

Water samples

d- $\mu$ SPE $(15 \mathrm{ml})$

HPLC-UV

Rodent plasm

MEPS

GC-MS

LLME

Human urine

MEPS (500) GC-MS

LLE (2500)

SPE (HLB, 2000)

$\operatorname{SPE}\left(\mathrm{C}_{18}, 3000\right)$

HF-LPME

GC-ECD

$0.5-3 /-$

$0.02-1.10 /-$

$0.02-1.0 /-$

$0.01-0.20 /-$

0.01-0.45/— 3-7.9/7.9-10.3 -

$15-21.3 /$ -

92-98

5.1-8.5/ $\quad 83-98$

$8.8-12.36$

83-98

$0.008-0.01$

$0.025-2.16$

$0.014-0.828 /$

$0.046-2.732$

$0.062-0.099 /-$

$0.03-7.40$

110

$1.0-10.1 /-$

$-/ 2.3-4.9$

78-99

$0.03-0.29 /-$

$0.17-0.93 /-$

$82-96$

10.2-27.2/- 67-122

$1.3-2.7 / \quad 86-99$

$1.7-3.3$

0.03-1.10/一 $\quad 2.0-8.9 /-\quad 86-114$

$0.08-1.3 /-\quad 4.3-9.8 /-$

5-20000 $\quad$ ACN (pH 8.0) (20) $\quad 1.07-16.2 / 3.21-48.7 \quad 0.503-9.15 /-\quad 89-107$

100-10 $000 \quad 95 \% \mathrm{MEOH}: 0.1 \% \mathrm{NaOH} \quad 30 / 100$

$95 \% \mathrm{MEOH}$
$(8 \times 20)$

MEOH $(1 \mathrm{ml})$

100-10 000

$95 \%(\mathrm{MEOH}: 1 \%$ (200)

$-1-$

$-1-$

100-10000 MeOH $(8 \times 25)$

$\mathrm{MeOH}(1 \mathrm{ml})$

$0.8-500 / 1-1000 \quad$ IPA

- $\quad$ ACN $(4 \times 90) /$ EtAc

(700)

$0.05-25$

IC/hex

$(1: 2: 97)(2 \times 40)$

$-$

$8-10 / 25-33$

$-1-$

45-87

94-100

(5000)
30/100-1000

$0.70-14.9$

$0.22-13.5$

$-/ 20-30 \quad-1-$

$0.21-0.51 / 0.71-1.70$

$-1-$

$-/ 0.06-0.08$

$0.02-0.08 /-$

$0.05-0.1 /-$

$0.002-0.019 /$

$0.007-0.062$

$1.6-12 /-$

$1.2-5.1$

$<5 /-$

10-20/-

0.7-6.6/

4.3-10.8

$1.2-9.3 /$

$1.7-13.9$

$5.0-12.0 /-$
$<70$

2-14/3-14 $\quad 80-120$

4.8-14.6/-

74-114

87-121

-12.0/— -




\begin{tabular}{|c|c|c|c|c|c|c|c|c|}
\hline Class (analytes) ${ }^{\mathrm{Ref}}$ & Sample matrix & $\begin{array}{l}\text { Extraction } \\
\text { (sample } \\
\text { volume, } \mu \mathrm{L} \text { ) }\end{array}$ & Analysis & $\begin{array}{l}\text { Linear range } \\
\left(\mathrm{ng} \mathrm{ml}^{-1}\right)\end{array}$ & $\begin{array}{l}\text { Elution solvent* } \\
(V, \mu \mathrm{l})\end{array}$ & $\begin{array}{l}\mathrm{LOD} / \mathrm{LOQ} \\
\left(\mathrm{ng} \mathrm{ml}^{-1}\right)\end{array}$ & RSD $(\%)$ & $\begin{array}{l}\text { Recovery } \\
(\%)\end{array}$ \\
\hline \multirow[t]{9}{*}{ Triazine herbicides } & Maize $^{146}$ & MEPS & HPLC-DAD & $2.5-300$ & EtAc $(400)$ & $-/ 35-108\left(\mathrm{pg} \mathrm{g}^{-1}\right)$ & $\begin{array}{l}1.0-6.9 / \\
4.6-7.8\end{array}$ & 91.5-101 \\
\hline & $\operatorname{Corn}^{147}$ & MEPS & HPLC-MS & $2.0-200$ & $\mathrm{ACN}(2 \mathrm{ml})$ & $\begin{array}{l}0.01-0.12 / 0.04-0.35 \\
\left(\mathrm{ng} \mathrm{g}^{-1}\right)\end{array}$ & $0.10-14.6$ & $73-107$ \\
\hline & Oilseed $^{173}$ & MSPD-DLLME & UFLC-UV & $8-1000$ & $\begin{array}{l}50 \% \mathrm{EtAc} \\
(1.5 \mathrm{ml})\end{array}$ & $\begin{array}{l}1.20-2.72 \\
\left(\mathrm{ng} \mathrm{g}^{-1}\right)\end{array}$ & $<7.7$ & $86-106$ \\
\hline & Soybean $^{189}$ & NPSMAE & HPLC-DAD & $5-513$ & $\mathrm{MeOH}(2 \mathrm{ml})$ & $1.56-2.00\left(\mathrm{ng} \mathrm{g}^{-1}\right)$ & $<6.7$ & $91-107$ \\
\hline & Water $^{190}$ & SUPRAS-MNP & HPLC-UV & $300-250000$ & $\mathrm{MeOH}(60)$ & $300-500$ & $4.6-6.5$ & $90-105$ \\
\hline & Rice $^{191}$ & SPE & HPLC-UV & $5-1000$ & $\begin{array}{l}\text { diethyl ether } \\
(3 \mathrm{ml})\end{array}$ & $\begin{array}{l}0.71-1.082 .67-3.64 \\
\left(n g g^{-1}\right)\end{array}$ & $<8.45$ & $89-100$ \\
\hline & Orange juice ${ }^{192}$ & SPE & GC-MS & $0.1-1000$ & $\mathrm{MeOH}(200)$ & $0.03-0.6$ & $3-11.4$ & $75-125$ \\
\hline & Juices ${ }^{180}$ & $\mathrm{dM}-\mu \mathrm{SPE}$ & HPLC-DAD & - & - & $0.23-1.6 / 0.76-5.3$ & $1.9-5.4$ & $98.2-99.4$ \\
\hline & Waste water ${ }^{181}$ & VAdM-SPME & HPLC-DAD & - & - & $2.0-5.3 / 6.1-15.7$ & $\begin{array}{l}5.8-10.2 / \\
3.8-6.3\end{array}$ & $97.6-101.5$ \\
\hline \multirow[t]{7}{*}{ Tetracycline residues } & Milk & MEPS $^{143}$ & HPLC-MS/MS & $15-110$ & $\mathrm{MeOH}(6 \times 100)$ & $0.03-0.21 / 0.05-0.9$ & $-1-$ & - \\
\hline & Milk & LLE $^{193}$ & HPLC-MS/MS & $15-110$ & EtAc $(6 \mathrm{ml})$ & $\left.-/ 5(\mu \mathrm{g} \mathrm{kg})^{-1}\right)$ & $-/ 13.0-29.0$ & - \\
\hline & Milk, eggs & FIL-NOSM ${ }^{194}$ & HPLC-UV & $0.5-500$ & - & $\begin{array}{l}0.08-1.12 /-(\mu \mathrm{g} \\
\left.\mathrm{kg}^{-1}\right)\end{array}$ & $\begin{array}{l}1.0-3.7 / \\
1.1-5.7\end{array}$ & $94-102$ \\
\hline & Infant foods & SALLE $^{195}$ & UHPLC-MS/MS & $15-110$ & $\mathrm{ACN}(3.2 \mathrm{ml})$ & $0.05-0.14 / 0.16-0.48$ & $\begin{array}{l}3.7-7.3 / \\
5.8-11.3\end{array}$ & $89-97$ \\
\hline & Beef & DLLME $^{172}$ & HPLC-MS/MS & $25000-200000$ & $\begin{array}{l}\text { MeOH : DCM } \\
(5: 1)(1.2 \mathrm{ml})\end{array}$ & $2.0-3.6 / 7.4-11.5$ & $-1-$ & $80-105$ \\
\hline & Animal tissue & $\mathrm{SPE}^{196}$ & HPLC-MS/MS & $0.2-500$ & $\begin{array}{l}\text { MeOH : EtAc } \\
(10 \mathrm{ml})\end{array}$ & $0.5-4.0 / 2-10$ & $<10 /<14$ & $54-102$ \\
\hline & Honey $^{182}$ & MF-SPME & HPLC-MS/MS & $\begin{array}{l}0.005-100 \\
\left(\mu \mathrm{gg} \mathrm{kg}^{-1}\right)\end{array}$ & - & $0.007-0.017\left(\mu \mathrm{g} \mathrm{kg}^{-1}\right)$ & $\begin{array}{l}5.0-9.5 / \\
3.6-10.0\end{array}$ & $70.5-111.0$ \\
\hline \multirow[t]{3}{*}{ Carnitine, acylcarnitines } & Urine & $\operatorname{MEPS}(100)^{31}$ & $\begin{array}{l}\text { UHPLC-MS/ } \\
\text { MS }\end{array}$ & $0.1-500$ & C2-ACN (100) & $0.1 /-$ & $-1-$ & - \\
\hline & & $\begin{array}{l}\text { Evaporation } \\
(50)^{197}\end{array}$ & $\mathrm{CE}$ & & $\begin{array}{l}\text { M1-20 mM } \\
\text { pyridine in ACN } \\
(100)\end{array}$ & $1.6 /-$ & $\begin{array}{l}1.5-10.2 / \\
2.6-21.0\end{array}$ & - \\
\hline & $\begin{array}{l}\text { Human sera, rat } \\
\text { tissue }^{198}\end{array}$ & $\begin{array}{l}\text { SLE }(15 \mu \mathrm{L} \\
\text { serum, } 10 \mathrm{mg} \\
\text { tissue })\end{array}$ & $\begin{array}{l}\text { UHP-HILIC- } \\
\text { MS/MS }\end{array}$ & $5-600$ & $\begin{array}{l}\mathrm{ACN}: \mathrm{MeOH} \\
(3: 1) \\
(65150)\end{array}$ & $0.5-5 /-$ & $\begin{array}{l}1.2-29.3 / \\
1.2-36.3\end{array}$ & $>88$ \\
\hline
\end{tabular}

Legend: * - elution solvent composition is indicated in $\mathrm{v} / \mathrm{v}$ ratios and these are discriminated in the table only when they are not equivalent among the components of the mixtures used; $*$

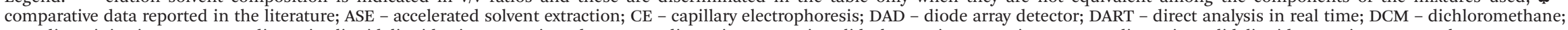

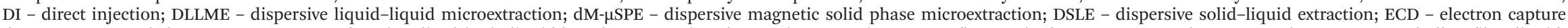

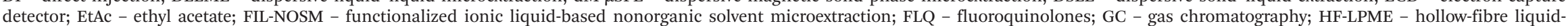

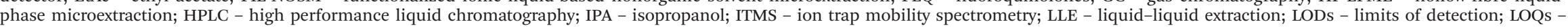

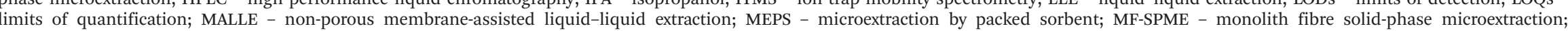
MHS-SDME - magnetic headspace single-drop microextraction; MIPs - molecularly imprinted polymers; MISPE - molecular imprint SPE; MS - mass spectrometry; MS/MS - tandem MS; MSPD - matrix solid-phase dispersion; NACE - non-aqueous capillary electrophoresis; NPD - nitrogen phosphorus detector; NSAIDs - non-steroidal anti-inflammatory drugs; NPSMAE - non-polar solvent microwave

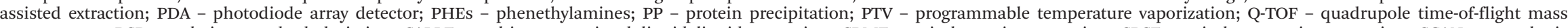

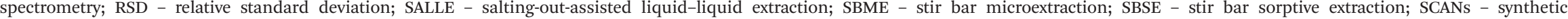

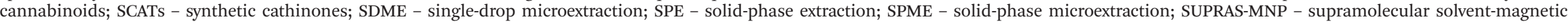

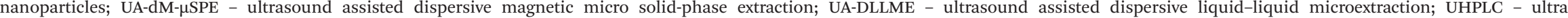

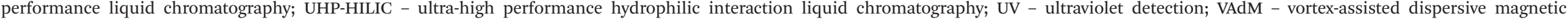
extraction. 
mercially available for MEPS can be found elsewhere. ${ }^{6}$ There is, nevertheless, a significant number of MEPS applications using custom sorbents, such as graphene ${ }^{69,143}$ and other nanomaterials, ${ }^{80,145-147,199,200}$ as well as molecularly imprinted polymers (MIPs) ${ }^{106-108,110}$ and imprinted interpenetrating polymer networks (IPNs), ${ }^{57}$ that are not commercially available. These sorbents were shown to provide better selectivity, but their limited production and packing in home-made syringes, such as $1 \mathrm{~mL}$ glass insulin injection syringes, ${ }^{77,84,86}$ or similar low-volume syringes, limit their use in the manual MEPS mode. An exception to this are the polymer monoliths ${ }^{201}$ and the poly(ethylene glycol) functionalization of monolithic poly(divinyl benzene) ${ }^{202}$ sorbents that Candish et al. packed in the MEPS BINs to be compatible with the semiautomatic eVol® syringe. An on-line MEPS architecture using custom sorbents was also reported by Abdel-Rehim et al. for the extraction of sarcosine from biological fluids ${ }^{37}$ and beta-blockers from plasma. ${ }^{61}$ However, these applications require some skills and customizations to interface MEPS with the LC-MS/MS configurations described that are not easy to implement for routine use. At the instrument level, the first commercial MEPS format available was manually driven through a Hamilton-type syringe. This configuration is simple and fast to operate, but it is not very prone to automatization. Moreover, it is too much exposed to experimental errors that inevitably arose from repetitive operation steps performed by the human subjects. The electronic syringe eVol ${ }^{\circledR}$ was a breakthrough in MEPS extraction, allowing a significant automation of the experimental procedure which became very close to what an autosampler can offer, but for one tenth of the price. The eVol® is a hand-held dispensing system for controlled positive displacement with in-built and intuitive programming functions. This is very convenient as it allows an easy customization of repetitive procedures. Furthermore, it is particularly useful for MEPS extractions which involve many repetitive operation steps of loading and dispensing of solvents, samples and washing solutions, eventually using different aspirating and dispensing velocities. The indicative number of operation steps can vary from 8 up to 20 steps or more, depending on the volume of the sample loaded by the cycle of extraction, the number of washing steps and even the elution process. Elution can include two successive steps to increase the target analyte recovery or even previous drying steps with air. In this way, eVol®-MEPS extraction is more reliable than manual MEPS, exhibiting better reproducibility and repeatability. Finally, the online and fully automatic MEPS approaches using autosamplers are still very expensive and in the last five years only two applications using this format were reported. ${ }^{42,67}$ In MEPS operation, the samples and solvents are loaded and discarded through the same channel. This may be particularly critical for target analytes with weak interactions with the sorbent. These analytes can be partially eluted and lost during the sample withdrawal and washing steps. And whilst in some cases it is possible to skip the washing step, for most applications this strategy will compromise the specificity of the method. To overcome this, a two-way valve laterally incorporated into the barrel of the syringe, designated controlled directional flow (CDF), was described by Candish et al. ${ }^{201-203}$ This CDF, represented in Fig. 2B, permits an independent flow path for the sample and solvents, which gives a better control over the direction of liquid flow. This allows, for instance, the loading of the elution solvent directly from the top of the sorbent bed, therefore reducing the possibility of dilution, carryover and any other contamination made during the bidirectional flow. The same principle applies for the washing solution, minimizing the target analyte loss during this step. The advantages of this CDF-MEPS architecture were shown by Candish et al. ${ }^{203}$ for the rapid screening of codeine metabolites in urine. This includes a very significant carryover effect reduction in comparison with traditional MEPS (1\% for CDF MEPS and 65\% for conventional MEPS), while conserving satisfactory analytical performance (recovery $>89 \%$ for $50 \mu \mathrm{L}$ sample, matrix effects $<42 \%$, linearity $r^{2}>0.99$, and LODs $<5 \mathrm{ng} \mathrm{mL}^{-1}$ ). The same researchers used the CDF-MEPS approach to assay new sorbents and their protein clean-up properties, namely polymer monoliths ${ }^{201}$ and the poly(ethylene glycol) functionalization of monolithic poly(divinyl benzene). ${ }^{202}$ The CDF-MEPS was also used by Elmongy et al. ${ }^{60}$ to extract metoprolol enantiomers from human plasma and saliva. In this case, the CDF path was used as the inlet to load the samples. More recently, a new improvement to MEPS was introduced in the market by EPREP company (Victoria, Australia). This variant, named $\mu$ SPEed extraction, represents a major upgrade by including several important modifications to MEPS extraction. As can be observed in Fig. 2C, the $\mu$ SPEed cartridge architecture contains an efficient pressure-driven one-way check valve. This allows an ultra-low dead volume connection and a single way flow path through the sorbent bed in every step of the extraction protocol. In this way, the aspiration can be achieved only by means of vacuum when the plunger is pulled back, and therefore, does not have to pass the bed but bypasses the sorbent. Essentially this a more elegant and efficient operation mode than the CDF-MEPS because the entire system is incorporated into a single cartridge, not requiring additional tubes and fittings. Another very relevant modification in $\mu$ SPEed is concerned with the use of smaller sorbent particles $(3 \mu \mathrm{m}$ or smaller) in a small cartridge, instead of the $50 \mu \mathrm{m}$ diameter particles normally used in traditional MEPS. These small particles, which are available in the equivalent MEPS chemistries, offer a higher surface area, therefore favouring a more efficient separation. For this reason, $\mu$ SPEed cartridges resemble a short ( $<1 \mathrm{~cm}$ long) sub $2 \mu \mathrm{m}$ liquid chromatography column. The high-pressure fitting of the $\mu$ SPEed, which is plug and play and not screw type as in MEPS, is also more advantageous, allowing an easy rejection of the used cartridge. This is particularly relevant for the use of autosamplers as $\mu$ SPEed cartridges can be switch or discarded without any operator intervention. Furthermore, unlike MEPS BINs, $\mu$ SPEed cartridges are made in polypropylene and so they are less expensive and suitable to single use protocols. Both these features are particularly tailored for applications in which a single use of the sorbent is mandatory for safety, quality control or regu- 


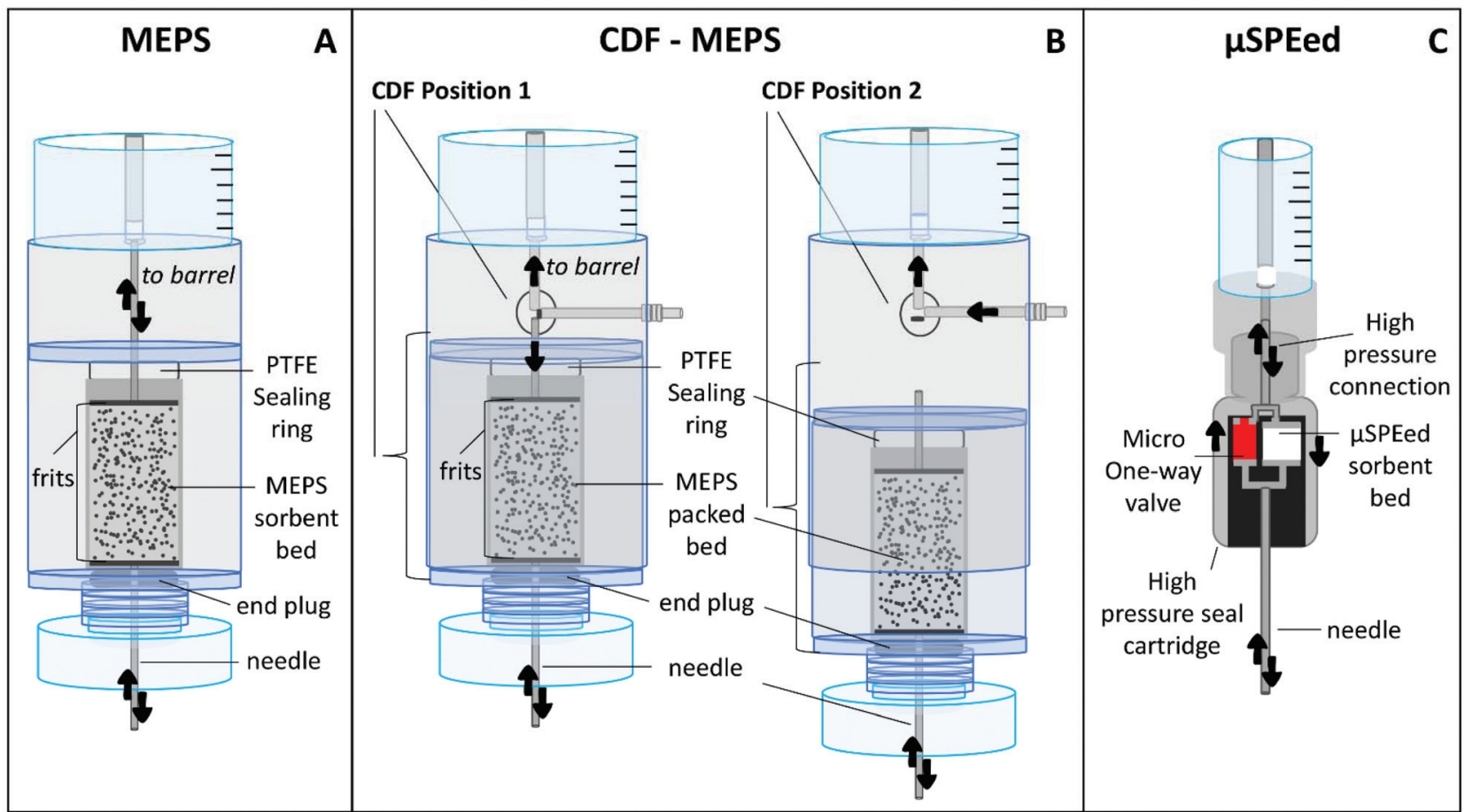

Fig. 2 Overview of different MEPS formats currently available: (A) original MEPS architecture with a two-way flow, (B) CDF-MEPS architecture with a lateral flow tube allowing a second injection path, and (C) $\mu$ SPEed architecture, with a pressure-driven one-way valve originating a single direction and flow path.

latory reasons. This is the case, for instance, of clinical applications involving biological fluids and high throughput analysis. The $\mu$ SPEed design also allows a constant, high pressure (up to $1600 \mathrm{psi}$ ) and single direction flow through the small particle size sorbent, retrieving more efficient extractions of the target analytes. Consequently, better performance can be attained in the following analytical procedures. The simpler and cheaper design of $\mu$ SPEed cartridges will certainly facilitate the assay of custom and more efficient sorbents, as well as their faster incorporation into the commercial supply chains. Finally, it should also be noted that $\mu$ SPEed cartridges can be operated using the standard eVol ${ }^{\circledR}$ syringe or the new eXact ${ }^{3}$ Digital Syringe Driver (EPREP). This second syringe is more potent and can cope with much higher backpressures, what can be very advantageous for the extraction of more complex samples that often cause sorbent clogging. However, unlike the cordless $\mathrm{eVol} \circledast$, the eXact $^{3}$ requires a continuous power connection to operate. Meanwhile, the potential of $\mu$ SPEed extraction has been already shown in three different applications. Porto-Figueira et al. ${ }^{204}$ reported the good analytical performance of this new approach in the analysis of phenolic compounds in teas by UHPLC-PDA. In turn, Alexandrou et $a l^{205}$ demonstrated that $\mu$ SPEed was faster and cheaper than traditional methods, attaining similar recovery rates for the determination of four common trihalomethane disinfection by-products in water. Moreover, the authors obtained this result using 1000 times less sample and 200 times less elution volumes. Also noteworthy is the report by Pandohee and
Jones ${ }^{206}$ that used the $\mu$ SPEed cartridges for on-column derivatisation of short-chain fatty acids in olive oil previously to the extraction procedure. This strategy unveils a whole new range of applications, where different chemical reactions, particularly derivatisations before the target analyte extraction, can be easily performed. Such achievement will streamline very significantly long, laborious, repetitive, and cumbersome experimental layouts. At a different level, it should also refer to a major simplification of the experimental layout involving MEPS. This is the case of the direct coupling of MEPS to the detection system, therefore skipping the chromatographic separation. This remarkable shortening of the analytical path was already described for the analysis of opiates from urine samples using ESI-MS ${ }^{203}$ and for the detection of the rave drug ketamine in fruit juices using Q-TOF analysis. ${ }^{129}$

\section{Conclusions}

As a sample microextraction approach, MEPS is being successfully used in different fields of research. This is certainly related with its easy operation mode and broad properties of the sorbents commercially available. It is striking, however, that this usage is excessively focused on the $\mathrm{C}_{18}$ sorbent and remaining silica and the more effective polymeric sorbents are still marginally used. Overall, and taking into consideration the reports involving MEPS published in the last five years, its adoption as a preferential extraction approach seems to be 
somehow limited. The number of reports using MEPS, with an average of around 20 reports per year, is far below the ones involving SPE or SPME. This suggests that eventually the interest in MEPS is being hindered by some limitations, such as the costs, reusability and automation possibilities. The commercialization of $\mu$ SPEed, with a more efficient and flexible design, cheaper and easier to incorporate in high-throughput analysis, has the potential to overcome the problems identified and allows a wider use of microextraction in forensic, clinical, and pharmaceutical analyses. The innovative $\mu$ SPEed architecture also facilitates the packing of new materials, and consequently the transition of promising proof of concept applications to the commercial circuits will be favoured. Finally, the use of $\mu$ SPEed as a reaction vessel for different biochemical reactions will be a breakthrough in the simplification of several experimental layouts covering the most diverse research applications, particularly the clinical, pharmaceutical and metabolomics analyses.

\section{Abbreviations}

\begin{tabular}{|c|c|c|}
\hline $\mathrm{ACN}$ & Acetonitrile & NPD \\
\hline AMPHs & Amphetamines & NSAIDs \\
\hline ANAEs & Anaesthetics & NPSMAE \\
\hline APS & Aminopropyl silane MEPS sorbent & OCPs \\
\hline ASE & Accelerated solvent extraction & OPFRs \\
\hline BDEs & Brominated diphenyl ethers & OPIs \\
\hline CD-IMS & Corona discharge ion mobility spectrometry & OPPs \\
\hline $\mathrm{CDF}$ & Controlled directional flow & PAEs \\
\hline $\mathrm{CE}$ & Capillary electrophoresis & P buffer \\
\hline CLC & Capillary liquid chromatography & PAHs \\
\hline CNTs & Carbon nanotubes & PANI \\
\hline $\mathrm{CNT} / \mathrm{PDPA}$ & CNTs/ polydiphenylamine & PCBs \\
\hline $\mathrm{COC}$ & Cocaine & PDA \\
\hline $\mathrm{DAD}$ & Diode array detector & PEs \\
\hline DART & Direct analysis in real time & PEP \\
\hline DI & Direct injection & PGC \\
\hline DIC & Diisopropylcarbodiimide & PHES \\
\hline DLLME & Dispersive liquid-liquid microextraction & PIP \\
\hline DMIP & Dummy molecularly imprinted polymer & $\mathrm{PP}$ \\
\hline ECD & Electron capture detector & PTV \\
\hline EDCs & Endocrine disrupting chemicals & Q-TOF \\
\hline EtAc & Ethyl acetate & $\mathrm{R}(\mathrm{A} / \mathrm{C}) \mathrm{X}$ \\
\hline EtOH & Ethanol & \\
\hline FA & Formic acid & \\
\hline FID & Flame ionization detector & RSD \\
\hline \multirow[t]{2}{*}{ FIL-NOSM } & Functionalized ionic liquid-based nonorganic & SALLE \\
\hline & solvent microextraction & SAX \\
\hline FLD & Fluorescence detection & SBME \\
\hline FLQ & Fluoroquinolones & SBSE \\
\hline GC & Gas chromatography & SDME \\
\hline HAAs & Haloacetic acids & SCANs \\
\hline HDVB & Highly crosslinked polystyrene divinylbenzene & SCATs \\
\hline hex & Hexane & SCX \\
\hline HFIP & 1,1,1,3,3,3-Hexafluoroisopropanol & SDVB \\
\hline
\end{tabular}

Hollow-fibre liquid-phase microextraction Hydrophilic interaction chromatography High performance liquid chromatography Isopropanol

Ion trap mobility spectrometry

Liquid-liquid extraction

Limits of detection

Limit of quantification

Large volume injection

Mixed-mode C8/SCX MEPS sorbent

MALLE

$\mathrm{MeOH}$

MEPS

MIBK

MIPs

MISPE

MS

MS/MS

MSPD

MTBE

NACE

NPD

NSAIDs

OCPS

OPFRs

OPIs

Non-porous membrane-assisted liquid-liquid extraction

Methanol

Microextraction by packed sorbent

Methyl isobutyl ketone

Molecularly imprinted polymers

Molecular imprint SPE

Mass spectrometry

Tandem MS

Matrix solid-phase dispersion

Methyl tert-butyl ether

Non-aqueous capillary electrophoresis

Nitrogen phosphorus detector

Non-steroidal anti-inflammatory drugs

Non-polar solvent microwave assisted extraction

Organochlorines

Organophosphate ester flame retardants

Opioids

Organophosphorus

Phthalate esters

Phosphate buffer

Polycyclic aromatic hydrocarbons

Polyaniline

Polychlorinated biphenyls

Photodiode array detector

Phthalate esters

Polar enhanced polymer MEPS sorbent

Porous graphitic carbon MEPS sorbent

Phenethylamines

Piperazine

Protein precipitation

Programmable temperature vaporization

Quadrupole time-of-flight mass spectrometry

Polymeric DVB partially functionalized with quaternary amine groups or sulfonic acid groups, respectively

Relative standard deviation

Salting-out-assisted liquid-liquid extraction

Strong anion exchange

Stir bar microextraction

Stir bar sorptive extraction

Single-drop microextraction

Synthetic cannabinoids

Synthetic cathinones

Strong cation exchange MEPS sorbent

Polystyrene divinylbenzene 


$\begin{array}{ll}\text { SERS } & \text { Surface-enhanced Raman spectroscopy } \\ \text { SIC } & \text { Sequential injection chromatography } \\ \text { Sil } & \text { Silica MEPS sorbent } \\ \text { Si-G } & \text { Graphene supported on aminopropyl silica } \\ \text { SPE } & \text { Solid-phase extraction } \\ \text { SPME } & \text { Solid-phase microextraction } \\ \text { SVOCs } & \text { Semi-VOCs } \\ \text { SUPRAS-MNP } & \text { Supramolecular solvent - magnetic } \\ & \text { nanoparticles } \\ \text { THC } & \text { Tetrahydrocannabinol } \\ \text { UA-DLLME } & \text { Ultrasound assisted dispersive liquid-liquid } \\ & \text { microextraction } \\ \text { UHPLC } & \text { Ultra performance liquid chromatography } \\ \text { UHP-HILIC } & \text { Ultra-high performance-hydrophilic inter- } \\ & \text { action liquid chromatography } \\ \text { UV } & \text { Ultraviolet detection } \\ \text { VAX } & \text { Polymeric DVB partially functionalized with } \\ & \text { quaternary amine groups (verify AX) } \\ \text { VAMD } & \text { Vortex-assisted magnetic dispersive } \\ \text { VOCs } & \text { Volatile organic compounds } \\ \text { VSMC/CMC } & \text { Vascular smooth muscle cells/cell membrane } \\ \mu & \text { chromatography } \\ \mu \text { MESI } & \text { Microelectron-capture detector } \\ & \text { Micropillar array electrospray ionization chip }\end{array}$

\section{Conflicts of interest}

The authors have no conflict of interest to declare.

\section{Acknowledgements}

The authors acknowledge FCT-Fundação para a Ciência e a Tecnologia (projects PEst-OE/QUI/UI0674/2019, CQM, Portuguese Government funds), and the Madeira 14-20 Program, project PROEQUIPRAM - Reforço do Investimento em Equipamentos e Infraestruturas Científicas na RAM (M1420-01-0145-FEDER-000008) and ARDITI-Agência Regional para o Desenvolvimento da Investigação Tecnologia e Inovação, through the project M1420-01-0145-FEDER-000005 - Centro de Química da Madeira - CQM+ (Madeira 14-20). JAMP and JAF were supported, respectively, by Post-Doctoral and Doctoral fellowships given by ARDITI (Project M1420 - 09-5369-FSE-000001), SM was also supported by ARDITI (ARDITI-CQM/2017/ 008-PDG), while RP, PPF, JG and VA were supported by FCT (Post-Doctoral fellowship SFRH/BPD/97387/2013 and Doctoral fellowships SFRH/BD/129630/2017, SFRH/BD/116895/2016 and SFRH/BD/117426/2016, respectively).

\section{References}

1 M. Abdel-Rehim, J. Chromatogr. B: Anal. Technol. Biomed. Life Sci., 2004, 801, 317-321.

2 M. Abdel-Rehim, Anal. Chim. Acta, 2011, 701, 119-128.
3 M. Abdel-Rehim, J. Chromatogr. A, 2010, 1217, 2569-2580.

4 M. Abdel-Rehim, Bioanalysis, 2009, 1, 687-691.

5 M. M. Moein, A. Abdel-Rehim and M. Abdel-Rehim, TrAC, Trends Anal. Chem, 2015, 67, 34-44.

6 J. Pereira, J. Gonçalves, V. Alves and J. S. Câmara, Sample Prep., 2013, 38-53, DOI: 10.2478/sampre-2013-0005.

7 G. Alves, M. Rodrigues, A. Fortuna, A. Falcao and J. Queiroz, Bioanalysis, 2013, 5, 1409-1442.

8 L. G. Blomberg, Anal. Bioanal. Chem., 2009, 393, 797807.

9 J. Pereira, J. S. Camara, A. Colmsjo and M. Abdel-Rehim, Biomed. Chromatogr., 2014, 28, 839-847.

10 J. Pereira, C. L. Silva, R. Perestrelo, J. Goncalves, V. Alves and J. S. Camara, Anal. Bioanal. Chem., 2014, 406, 21012122.

11 H. Vlckova, P. Svoboda, O. Novak, P. Solich and L. Novakova, Bioanalysis, 2016, 8, 333-349.

12 T. Hyötyläinen, Anal. Bioanal. Chem., 2009, 394, 743-758.

13 C. Kim, H.-D. Ryu, E. G. Chung, Y. Kim and J.-K. Lee, J. Environ. Manage., 2018, 217, 629-645.

14 C. Silva, C. Cavaco, R. Perestrelo, J. Pereira and J. Câmara, Metabolites, 2014, 4, 71-97.

15 J. Wang, J. D. MacNeil and J. F. Kay, Chemical analysis of antibiotic residues in food, John Wiley \& Sons, 2011.

16 H. Kataoka, TrAC, Trends Anal. Chem, 2003, 22, 232-244.

17 H. Kataoka, Anal. Bioanal. Chem., 2010, 396, 339-364.

18 M. R. Siddiqui, Z. A. Aiothman and N. Rahman, Arabian J. Chem, 2017, 10, S1409-S1421.

19 A. Kabir, R. Mesa, J. Jurmain and K. G. Furton, Separations, 2017, 4, 21.

20 D. M. Pavlovic, S. Babic, A. J. M. Horvat and M. KastelanMacan, TrAC, Trends Anal. Chem, 2007, 26, 1062-1075.

21 M. M. Moein, A. El Beqqali and M. Abdel-Rehim, J. Chromatogr. B: Anal. Technol. Biomed. Life Sci., 2017, 1043, 3-11.

22 Z. Altun, M. Abdelrehim and L. Blomberg, J. Chromatogr. B: Anal. Technol. Biomed. Life Sci., 2004, 813, 129-135.

23 V. Alves, J. Goncalves, C. Conceicao, H. M. Teixeira and J. S. Camara, J. Chromatogr. A, 2015, 1408, 30-40.

24 M. Szultka, R. Krzeminski, J. Szeliga, M. Jackowski and B. Buszewski, J. Chromatogr. A, 2013, 1272, 41-49.

25 V. D’Angelo, F. Tessari, G. Bellagamba, E. De Luca, R. Cifelli, C. Celia, R. Primavera, M. Di Francesco, D. Paolino, L. Di Marzio and M. Locatelli, J. Enzyme Inhib. Med. Chem., 2016, 31, 110-116.

26 I. M. Viana, P. Lima Pde, C. D. Soares and C. Fernandes, J. Pharm. Biomed. Anal., 2014, 96, 241-248.

27 J. L. Gonçalves, V. L. Alves, C. J. F. Conceição, H. M. Teixeira and J. S. Câmara, Microchem. J., 2015, 123, 90-98.

28 D. Lourenco, M. Sarraguca, G. Alves, P. Coutinho, A. R. T. S. Araujo and M. Rodrigues, Anal. Methods, 2017, 9, 5910-5919.

29 V. Ferrone, M. Carlucci, R. Cotellese, P. Raimondi, A. Cichella, L. D. Marco and G. Carlucci, Talanta, 2017, 164, 64-68. 
30 C. Campestre, M. Locatelli, P. Guglielmi, E. De Luca, G. Bellagamba, S. Menta, G. Zengin, C. Celia, L. Di Marzio and S. Carradori, J. Enzyme Inhib. Med. Chem., 2017, 32, 1-11.

31 S. Magiera and J. Baranowski, J. Pharm. Biomed. Anal., 2015, 109, 171-176.

32 M. Ligor, T. Ligor, R. Gadzaa-Kopciuch and B. Buszewski, Biomed. Chromatogr., 2015, 29, 584-589.

33 C. K. Lim and G. Lord, Biol. Pharm. Bull., 2002, 25, 547-557.

34 M. M. Moein, R. Said, F. Bassyouni and M. Abdel-Rehim, J. Anal. Methods Chem., 2014, 2014, 921350.

35 A. Paudel, V. Kumar and S. Singh, Mass Spectrometry in Pharmaceutical Analysis, 2007.

36 M. Valcárcel, S. Cárdenas and R. Lucena, Analytical Microextraction Techniques, Bentham Science Publishers, 2017.

37 M. M. Moein, A. Abdel-Rehim and M. Abdel-Rehim, J. Sep. Sci., 2015, 38, 788-795.

38 G. Vasapollo, R. D. Sole, L. Mergola, M. R. Lazzoi, A. Scardino, S. Scorrano and G. Mele, Int. J. Mol. Sci., 2011, 12, 5908-5945.

39 A. Speltini, A. Scalabrini, F. Maraschi, M. Sturini and A. Profumo, Anal. Chim. Acta, 2017, 974, 1-26.

40 L. M. Madikizela, N. T. Tavengwa and L. Chimuka, J. Pharm. Biomed. Anal., 2018, 147, 624-633.

41 L. X. Yi, R. Fang and G. H. Chen, J. Chromatogr. Sci., 2013, 51, 608-618.

42 A. M. C. Ferreira, B. Moreno Cordero, A. P. Crisolino Pozas and J. L. Perez Pavon, J. Chromatogr. A, 2016, 1444, 32-41.

43 L. Konieczna, A. Roszkowska, A. Synakiewicz, T. Stachowicz-Stencel, E. Adamkiewicz-Drozynska and T. Baczek, Talanta, 2016, 150, 331-339.

44 N. Y. Ashri, M. Daryanavard and M. Abdel-Rehim, Biomed. Chromatogr., 2013, 27, 396-403.

45 F. Bianchi, M. Mattarozzi, N. Riboni, P. Mora, S. A. Gandolfi and M. Careri, J. Pharm. Biomed. Anal., 2017, 142, 343-347.

46 S. Magiera, S. Gulmez, A. Michalik and I. Baranowska, J. Chromatogr. A, 2013, 1304, 1-9.

47 M. Locatelli, V. Ferrone, R. Cifelli, R. C. Barbacane and G. Carlucci, J. Chromatogr. A, 2014, 1367, 1-8.

48 A. A. D’Archivio, M. A. Maggi, F. Ruggieri, M. Carlucci, V. Ferrone and G. Carlucci, J. Pharm. Biomed. Anal., 2016, 125, 114-121.

49 M. Locatelli, M. T. Ciavarella, D. Paolino, C. Celia, E. Fiscarelli, G. Ricciotti, A. Pompilio, G. Di Bonaventura, R. Grande, G. Zengin and L. Di Marzio, J. Chromatogr. A, 2015, 1419, 58-66.

50 V. Ferrone, M. Carlucci, P. Palumbo and G. Carlucci, J. Pharm. Biomed. Anal., 2016, 128, 313-321.

51 M. A. Saracino, L. Mercolini, G. Carbini, V. Volterra, A. L. Quarta, M. Amore and M. A. Raggi, J. Pharm. Biomed. Anal., 2014, 95, 61-67.

52 I. D. de Souza, D. S. Domingues and M. E. C. Queiroz, Talanta, 2015, 140, 166-175.

53 A. P. F. Catai, F. P. Picheli, E. Carrilho and M. E. C. Queiroz, J. Braz. Chem. Soc., 2013, 24, 1635-1641.
54 P. Magalhaes, G. Alves, A. Llerena and A. Falcao, J. Anal. Toxicol., 2017, 41, 631-638.

55 P. Magalhaes, G. Alves, M. Rodrigues, A. Llerena and A. Falcao, Bioanalysis, 2014, 6, 3025-3038.

56 A. Ferreira, M. Rodrigues, P. Oliveira, J. Francisco, A. Fortuna, L. Rosado, P. Rosado, A. Falcao and G. Alves, J. Chromatogr. B: Anal. Technol. Biomed. Life Sci., 2014, 971, 20-29.

57 S. Asgari, H. Bagheri, A. Es-haghi and R. AminiTabrizi, J. Chromatogr. A, 2017, 1491, 1-8.

58 S. Ventura, M. Rodrigues, S. Pousinho, A. Falcao and G. Alves, J. Chromatogr. B: Anal. Technol. Biomed. Life Sci., 2016, 1035, 67-75.

59 M. Rodrigues, G. Alves, M. Rocha, J. Queiroz and A. Falcao, J. Chromatogr. B: Anal. Technol. Biomed. Life Sci., 2013, 913-914, 90-97.

60 H. Elmongy, H. Ahmed, A. A. Wahbi, A. Amini, A. Colmsjo and M. Abdel-Rehim, Biomed. Chromatogr., 2016, 30, 1309-1317.

61 T. Abuzooda, A. Amini and M. Abdel-Rehim, J. Chromatogr. B: Anal. Technol. Biomed. Life Sci., 2015, 992, 86-90.

62 B. M. da Fonseca, I. E. Moreno, M. Barroso, S. Costa, J. A. Queiroz and E. Gallardo, Anal. Bioanal. Chem., 2013, 405, 3953-3963.

63 L. Mercolini, M. Protti, G. Fulgenzi, R. Mandrioli, N. Ghedini, A. Conca and M. A. Raggi, J. Pharm. Biomed. Anal., 2014, 88, 467-471.

64 H. Vlckova, J. Janak, T. Gottvald, F. Trejtnar, P. Solich and L. Novakova, J. Pharm. Biomed. Anal., 2014, 88, 337344.

65 S. Magiera, J. Chromatogr. B: Anal. Technol. Biomed. Life Sci., 2013, 938, 86-95.

66 S. Magiera and J. Kusa, J. Chromatogr. B: Anal. Technol. Biomed. Life Sci., 2015, 980, 79-87.

67 I. Sramkova, P. Chocholous, H. Sklenarova and D. Satinsky, Talanta, 2015, 143, 132-137.

68 S. M. Daryanavard, A. Jeppsson-Dadoun, L. I. Andersson, M. Hashemi, A. Colmjso and M. Abdel-Rehim, Biomed. Chromatogr., 2013, 27, 1481-1488.

69 M. Ahmadi, M. M. Moein, T. Madrakian, A. Afkhami, S. Bahar and M. Abdel-Rehim, J. Chromatogr. B: Anal. Technol. Biomed. Life Sci., 2018, 1095, 177-182.

70 B. Mendes, P. Silva, I. Mendonca, J. Pereira and J. S. Camara, Talanta, 2013, 116, 164-172.

71 B. Mendes, P. Silva, F. Aveiro, J. Pereira and J. S. Câmara, PLoS One, 2013, 8(3), e58366.

72 P. H. Berenguer, I. C. Camacho, R. Câmara, S. Oliveira and J. S. Câmara, J. Chromatogr. A, 2019, 1584, 42-56.

73 V. C. Jardim, L. de Paula Melo, D. Soares Domingues and M. E. Costa Queiroz, J. Chromatogr. B: Anal. Technol. Biomed. Life Sci., 2015, 974, 35-41.

74 A. El Beqqali, M. Ahmadi and M. Abdel-Rehim, J. Chromatogr. B: Anal. Technol. Biomed. Life Sci., 2017, 1043, 20-24.

75 R. Kaur, S. Rani, A. K. Malik and J. S. Aulakh, J. Sep. Sci., 2014, 37, 966-973. 
76 K. H. Kim, E. Kabir and S. A. Jahan, Sci. Total Environ., 2017, 575, 525-535.

77 A. Taghani, N. Goudarzi, G. Bagherian and M. A. Chamjangali, Anal. Sci., 2017, 33, 1135-1140.

78 B. H. Fumes, F. N. Andrade, A. J. d. S. Neto and F. M. Lanas, J. Sep. Sci., 2016, 39, 2823-2830.

79 C. R. de Morais, A. M. Bonetti, S. M. Carvalho, A. A. A. de Rezende, G. R. Araujo and M. A. Spanó, Chemosphere, 2016, 165, 342-351.

80 M. Saraji, M. T. Jafari and M. M. Amooshahi, J. Sep. Sci., 2018, 41, 493-500.

81 A. Celik, S. Y. Ekinci, G. Guler and S. Yildirim, DNA Cell Biol., 2014, 33, 148-154.

82 C. R. de Morais and S. M. A. Carvalho, Chemosphere, 2017, 187, 163-172.

83 S. H. Mehdi and A. Qamar, Toxicol. Sci., 2013, 134, 355-365.

84 A. Taghani, N. Goudarzi and G. Bagherian, J. Sep. Sci., 2016, 39, 4219-4226.

85 C. Santos, D. Oppolzer, A. Goncalves, M. Barroso and E. Gallardo, J. Anal. Toxicol., 2018, 42, 321-329.

86 A. Taghani, N. Goudarzi, G. A. Bagherian, M. Arab Chamjangali and A. H. Amin, J. Sep. Sci., 2018, 41, 2245-2252.

87 A. Klimowska and B. Wielgomas, Talanta, 2018, 176, 165171.

88 M. Quinto, G. Spadaccino, D. Nardiello, C. Palermo, P. Amodio, D. Li and D. Centonze, J. Chromatogr. A, 2014, 1371, 30-38.

89 M. P. Martínez-Moral and M. T. Tena, J. Chromatogr. A, 2014, 1364, 28-35.

90 A. Naccarato, R. Elliani, G. Sindona and A. Tagarelli, Anal. Bioanal. Chem., 2017, 409, 7105-7120.

91 R. Kaur, Heena, R. Kaur, S. Rani and A. K. Malik, J. Sep. Sci., 2016, 39, 923-931.

92 A. Amiri, M. Chahkandi and A. Targhoo, Anal. Chim. Acta, 2017, 950, 64-70.

93 E. Caballero-Díaz, B. M. Simonet and M. Valcarcel, Anal. Bioanal. Chem., 2013, 405, 7251-7257.

94 J. Cavalheiro, A. Prieto, M. Monperrus, N. Etxebarria and O. Zuloaga, Anal. Chim. Acta, 2013, 773, 68-75.

95 M. D. N. Sánchez, P. M. Santos, C. P. Sappo, J. L. Pavon and B. M. Cordero, Talanta, 2014, 119, 375-384.

96 G. G. Noche, M. E. Fernandez Laespada, J. L. Perez Pavon, B. Moreno Cordero and S. Muniategui Lorenzo, Anal. Bioanal. Chem., 2013, 405, 6739-6748.

97 M. Kaur, S. Rani, A. K. Malik and J. S. Aulakh, J. Chromatogr. Sci., 2014, 52, 977-984.

98 C. Haman, X. Dauchy, C. Rosin and J. F. Munoz, Water Res., 2015, 68, 1-11.

99 B. H. Fumes and F. M. Lancas, J. Chromatogr. A, 2017, 1487, 64-71.

100 A. M. C. Ferreira, M. E. Fernandez Laespada, J. L. Perez Pavon and B. M. Cordero, J. Chromatogr. A, 2013, 1318, 35-42.

101 R. M. Gonzalez Paredes, C. Garcia Pinto, J. L. Perez Pavon and B. Moreno Cordero, J. Chromatogr. A, 2014, 1359, 5259.
102 L. Yang, Q. Han, S. Cao, J. Yang, J. Zhao, M. Qin and M. Ding, J. Sep. Sci., 2016, 39, 1518-1523.

103 D. A. Capoferri, Talanta, 2017, 174, 599-604.

104 F. H. Salami and M. E. Queiroz, J. Chromatogr. Sci., 2013, 51, 899-904.

105 F. N. Andrade, A. J. Santos-Neto and F. M. Lancas, J. Sep. Sci., 2014, 37, 3150-3156.

106 C. F. Silva, K. B. Borges and C. S. do Nascimento, Analyst, 2017, 143, 141-149.

107 E. Soleimani, A. Bahrami, A. Afkhami and F. G. Shahna, Arch. Toxicol., 2018, 92, 213-222.

108 E. Soleimani, A. Bahrami, A. Afkhami and F. G. Shahna, Arch. Toxicol., 2018, 92, 223.

109 G. Dhingra, P. Bansal, N. Dhingra, S. Rani and A. K. Malik, J. Sep. Sci., 2018, 41, 639-647.

110 E. Soleimani, A. Bahrami, A. Afkhami and F. G. Shahna, J. Chromatogr. B: Anal. Technol. Biomed. Life Sci., 2017, 1061-1062, 65-71.

111 M. Barroso and E. Gallardo, Bioanalysis, 2014, 6, 1-3.

112 Y. He, $L C-G C, 2017,35,14-20$.

113 J. Siegel, Forensic Chemistry: Fundamentals and Applications, John Wiley \& Sons, 2015.

114 O. H. Drummer, in Forensic Toxicology, ed. M. M. Houck, Academic Press, 2016, ch. 1, pp. 25-30.

115 M. L. Smith, S. P. Vorce, J. M. Holler, E. Shimomura, J. Magluilo, A. J. Jacobs and M. A. Huestis, J. Anal. Toxicol., 2007, 31, 631-638.

116 L. Harper, J. Powell and E. M. Pijl, Harm. Reduct. J., 2017, 14, 52.

117 M. Barroso, I. Moreno, B. da Fonseca, J. A. Queiroz and E. Gallardo, Bioanalysis, 2012, 4, 1805-1826.

118 H. Miyaguchi, Y. T. Iwata, T. Kanamori, K. Tsujikawa, K. Kuwayama and H. Inoue, J. Chromatogr. A, 2009, 1216, 4063-4070.

119 T. Rosado, A. Goncalves, C. Margalho, M. Barroso and E. Gallardo, Anal. Bioanal. Chem., 2017, 409, 2051-2063.

120 P. Fernandez, M. Gonzalez, M. Regenjo, A. M. Ares, A. M. Fernandez, R. A. Lorenzo and A. M. Carro, J. Chromatogr. A, 2017, 1485, 8-19.

121 C. Montesano, M. C. Simeoni, R. Curini, M. Sergi, C. Lo Sterzo and D. Compagnone, Anal. Bioanal. Chem., 2015, 407, 3647-3658.

122 T. Rosado, L. Fernandes, M. Barroso and E. Gallardo, J. Chromatogr. B: Anal. Technol. Biomed. Life Sci., 2017, 1043, 63-73.

123 R. Rocchi, M. C. Simeoni, C. Montesano, G. Vannutelli, R. Curini, M. Sergi and D. Compagnone, Drug Test. Anal., 2018, 10, 865-873.

124 I. E. Moreno, B. M. da Fonseca, M. Barroso, S. Costa, J. A. Queiroz and E. Gallardo, J. Pharm. Biomed. Anal., 2012, 61, 93-99.

125 L. Magrini, A. Cappiello, G. Famiglini and P. Palma, J. Pharm. Biomed. Anal., 2016, 125, 48-53.

126 M. Piergiovanni, A. Cappiello, G. Famiglini, V. Termopoli and P. Palma, J. Pharm. Biomed. Anal., 2018, 154, 492500. 
127 I. Moreno, M. Barroso, A. Martinho, A. Cruz and E. Gallardo, J. Chromatogr. B: Anal. Technol. Biomed. Life Sci., 2015, 1004, 67-78.

128 A. M. Ares, P. Fernandez, M. Regenjo, A. M. Fernandez, A. M. Carro and R. A. Lorenzo, Talanta, 2017, 174, 454-461.

129 S. S. Sahota, J. Singh, G. Bansal and R. K. Garg, Curr. Sci., 2016, 110, 1059-1062.

130 M. Sergi, C. Montesano, S. Odoardi, L. Mainero Rocca, G. Fabrizi, D. Compagnone and R. Curini, J. Chromatogr. A, 2013, 1301, 139-146.

131 H. Vlckova, A. El-Beqqali, L. Novakova, P. Solich and M. Abdel-Rehim, J. Sep. Sci., 2014, 37, 3306-3313.

132 I. Moreno, B. Fonseca, D. Oppolzer, A. Martinho, M. Barroso, A. Cruz, J. A. Queiroz and E. Gallardo, Bioanalysis, 2013, 5, 661-668.

133 S. Anizan, E. Bichon, F. Monteau, N. Cesbron, J. P. Antignac and B. Le Bizec, J. Chromatogr. A, 2010, 1217, 6652-6660.

134 L. Mercolini, M. Protti, M. A. Saracino, M. Mandrone, F. Antognoni and F. Poli, Phytochem. Anal., 2016, 27, 4149.

135 J. L. Gonçalves, V. L. Alves, F. P. Rodrigues, J. A. Figueira and J. S. Câmara, J. Chromatogr. A, 2013, 1304, 42-51.

136 M. Rahimi, P. Hashemi, A. Badiei and M. Safdarian, J. Anal. Chem., 2016, 71, 35-41.

137 J. M. Leca, V. Pereira, A. C. Pereira and J. C. Marques, Anal. Chim. Acta, 2014, 811, 29-35.

138 M. L. Savastano, I. Losito and S. Pati, Food Control, 2016, 68, 391-398.

139 J. Freitas, R. Perestrelo, R. Cassaca, M. Castillo, M. Santos, J. Pereira and J. S. Camara, Food Chem., 2017, 214, 686693.

140 S. Anizan, E. Bichon, T. Duval, F. Monteau, N. Cesbron, J. P. Antignac and B. Le Bizec, J. Mass Spectrom., 2012, 47, 131-140.

141 W. Du, G. Zhao, Q. Fu, M. Sun, H. Zhou and C. Chang, Food Chem., 2014, 145, 789-795.

142 F. H. Salami and M. E. C. Queiroz, J. Braz. Chem. Soc., 2011, 22, 1656-1661.

143 E. Vasconcelos Soares Maciel, B. Henrique Fumes, A. Lucia de Toffoli and F. Mauro Lancas, Electrophoresis, 2018, DOI: 10.1002/elps.201800051.

144 F. Di Ottavio, F. Della Pelle, C. Montesano, R. Scarpone, A. Escarpa, D. Compagnone and M. Sergi, Food Anal. Methods, 2017, 10, 1699-1708.

145 M. M. Abolghasemi, H. Taheri, M. Jaymand and M. Piryaei, Sep. Sci. Plus, 2018, 1, 202-208.

146 X. Li, Y. Sun, L. Yuan, L. Liang, Y. Jiang, H. Piao, D. Song, A. Yu and X. Wang, Mikrochim. Acta, 2018, 185, 336.

147 Y. Jiang, P. Ma, X. Li, H. Piao, D. Li, Y. Sun, X. Wang and D. Song, J. Chromatogr. A, 2018, 1574, 36-41.

148 W. Haider, D. Barillier, A. Hayat, J. L. Gaillard and J. Ledauphin, Anal. Methods, 2014, 6, 1364-1376.

149 Z. Khoshdel, P. Hashemi, M. Safdaryan, B. Delfan, M. Rashidipour and A. Badiei, Anal. Sci., 2013, 29, 527532.
150 L. Bustamante, D. Cardenas, D. von Baer, E. Pastene, D. Duran-Sandoval, C. Vergara and C. Mardones, J. Sep. Sci., 2017, 40, 3487-3496.

151 P. Silva, C. L. Silva, R. Perestrelo, F. M. Nunes and J. S. Camara, J. Chromatogr. A, 2017, 1520, 117-126.

152 R. Perestrelo, C. L. Silva and J. S. Camara, J. Chromatogr. A, 2015, 1381, 54-63.

153 R. Perestrelo, E. Rodriguez and J. S. Camara, LWT - Food Sci. Technol., 2017, 76, 40-47.

154 L. P. Halinski and P. Stepnowski, Acta Chromatogr., 2015, 27, 729-741.

155 M. Li, S. Wang and L. He, J. Chromatogr. B Analyt. Technol. Biomed. Life. Sci., 2015, 974, 9-16.

156 X. Sun, X. Y. Jiao, J. Li and L. Xu, J. Chromatogr. A, 2018, 1543, 1-13.

157 S. S. Saini, Anal. Chem. Lett., 2018, 8, 9-24.

158 B. M. Botrel, D. C. Abreu, A. A. Saczk, M. J. Bazana, S. M. Coelho, P. V. Rosa, Z. M. Magriotis and R. M. de Lima, Food Chem., 2017, 229, 674-679.

159 L. O. Santos, J. P. dos Anjos, S. L. C. Ferreira and J. B. de Andrade, Microchem. J., 2017, 133, 431-440.

160 Z. Kafil, M. Babashpour-Asl and M. Piryaei, Nat. Prod. Res., 2018, 1-4, DOI: 10.1080/14786419.2018.1428587.

161 S. Somsubsin, K. Seebunrueng, S. Boonchiangma and S. Srijaranai, Talanta, 2018, 176, 172-177.

162 A. Amiri and F. Ghaemi, Microchim. Acta, 2017, 184, 38513858.

163 L. Nováková, J. Chromatogr. A, 2013, 1292, 25-37.

164 C. L. Silva, M. Passos and J. S. Camara, Talanta, 2012, 89, 360-368.

165 P. Porto-Figueira, A. Freitas, C. J. Cruz, J. Figueira and J. S. Camara, Food Res. Int., 2015, 77, 408-418.

166 V. Lucaire, J. J. Schwartz, O. Delhomme, R. OcampoTorres and M. Millet, Anal. Bioanal. Chem., 2018, 410, 1955-1963.

167 N. Scherer, K. Marcsekova, T. Posset and G. Winter, J. Pharm. Biomed. Anal., 2018, 152, 66-73.

168 A. Marsol-Vall, M. Balcells, J. Eras and R. Canela-Garayoa, Food Chem., 2018, 239, 119-125.

169 S. Rani and A. K. Malik, J. Sep. Sci., 2012, 1-8.

170 S. Rani, A. K. Malik and B. Singh, J. Sep. Sci., 2012, 35, 359-366.

171 G. G. Noche, M. E. Laespada, J. L. Pavon, B. M. Cordero and S. M. Lorenzo, J. Chromatogr. A, 2011, 1218, 93909396.

172 S. O. Mookantsa, S. Dube and M. M. Nindi, Talanta, 2016, 148, 321-328.

173 Y. Wang, Y. Sun, B. Xu, X. Li, X. Wang, H. Zhang and D. Song, Anal. Chim. Acta, 2015, 888, 67-74.

174 E. Fernandez, L. Vidal and A. Canals, Anal. Bioanal. Chem., 2018, 410, 4679-4687.

175 R. Mirzajani, N. Pourreza and J. Burromandpiroze, Ultrason. Sonochem., 2018, 40, 101-112.

176 A. A. Asgharinezhad, S. Karami, H. Ebrahimzadeh, N. Shekari and N. Jalilian, Int. J. Pharm., 2015, 494, 102112. 
177 C. Montesano, G. Vannutelli, V. Piccirilli, M. Sergi, D. Compagnone and R. Curini, Talanta, 2017, 167, 260-267.

178 H. Nsubuga and C. Basheer, J. Chromatogr. A, 2013, 1315, 47-52.

179 S. M. Abd Wahib, W. A. Wan Ibrahim, M. M. Sanagi, M. A. Kamboh and A. S. Abdul Keyon, J. Chromatogr. A, 2018, 1532, 50-57.

180 F. Liu, X. Yang, X. Wu, X. Xi, H. Gao, S. Zhang, W. Zhou and R. Lu, Food Chem., 2018, 268, 485-491.

181 A. Nasrollahpour and S. E. Moradi, J. AOAC Int., 2018, 101, 1639-1646.

182 M. Pei and X. Huang, J. Chromatogr. A, 2017, 1517, 1-8.

183 F. Lafay, E. Vulliet and M. M. Flament-Waton, Anal. Bioanal. Chem., 2010, 396, 937-941.

184 G. Rubasinghege, R. Gurung, H. Rijal, S. MaldonadoTorres, A. Chan, S. Acharya, S. Rogelj and M. Piyasena, Water Res., 2018, 131, 22-32.

185 T. Martinez-Sena, S. Armenta, M. Guardia and F. A. Esteve-Turrillas, J. Pharm. Biomed. Anal., 2016, 131, 48-53.

186 V. Ferrone, R. Cotellese, L. Di Marco, S. Bacchi, M. Carlucci, A. Cichella, P. Raimondi and G. Carlucci, J. Pharm. Biomed. Anal., 2017, 140, 266-273.

187 M. Paal, M. Zoller, C. Schuster, M. Vogeser and G. Schutze, J. Pharm. Biomed. Anal., 2018, 152, 102-110.

188 M. Ghorbani, M. Chamsaz and G. H. Rounaghi, J. Sep. Sci., 2016, 39, 1082-1089.

189 N. Li, L. Wu, L. Nian, Y. Song, L. Lei, X. Yang, K. Wang, Z. Wang, L. Zhang, H. Zhang, A. Yu and Z. Zhang, Talanta, 2015, 142, 43-50.

190 M. Safari, Y. Yamini, E. Tahmasebi and B. Ebrahimpour, Microchim. Acta, 2016, 183, 203-210.

191 X. Li, Y. Sun, Q. Sun, L. Liang, H. Piao, Y. Jiang, A. Yu, D. Song and X. Wang, J. Sep. Sci., 2017, 40, 2992-2998.
192 B. Fresco-Cala, S. Cárdenas and M. Valcárcel, Microchim. Acta, 2016, 183, 465-474.

193 C. Nebot, M. Guarddon, F. Seco, A. Iglesias, J. M. Miranda, C. M. Franco and A. Cepeda, Food Control, 2014, 46, 495-501.

194 J. Gao, H. Wang, J. Qu, H. Wang and X. Wang, Food Chem., 2017, 215, 138-148.

195 D. Moreno-Gonzalez and A. M. Garcia-Campana, Food Chem., 2017, 221, 1763-1769.

196 Z. Zhang, X. Li, S. Ding, H. Jiang, J. Shen and X. Xia, Food Chem., 2016, 204, 252-262.

197 L. Vernez, W. Thormann and S. Krahenbuhl, J. Chromatogr. A, 2000, 895, 309-316.

198 M. Kivilompolo, L. Ohrnberg, M. Oresic and T. Hyotylainen, J. Chromatogr. A, 2013, 1292, 189-194.

199 H. Bagheri, S. Banihashemi and F. K. Zandian, Microchim. Acta, 2016, 183, 195-202.

200 H. Bagheri, Z. Ayazi, A. Eshaghi and A. Aghakhani, J. Chromatogr. A, 2012, 1222, 13-21.

201 E. Candish, H.-J. Wirth, A. A. Gooley, R. A. Shellie and E. F. Hilder, J. Chromatogr. A, 2015, 1410, 9-18.

202 E. Candish, A. Khodabandeh, M. Gaborieau, T. Rodemann, R. A. Shellie, A. A. Gooley and E. F. Hilder, Anal. Bioanal. Chem., 2017, 409, 2189-2199.

203 E. Candish, A. Gooley, H. J. Wirth, P. A. Dawes, R. A. Shellie and E. F. Hilder, J. Sep. Sci., 2012, 35, 23992406.

204 P. Porto-Figueira, J. A. Figueira, J. A. Pereira and J. S. Câmara, J. Chromatogr. A, 2015, 1424, 1-9.

205 L. D. Alexandrou, M. J. S. Spencer, P. D. Morrison, B. J. Meehan and O. A. H. Jones, Sci. Total Environ., 2015, 512, 210-214.

206 J. Pandohee and O. A. H. Jones, Anal. Methods, 2016, 8, 1765-1769. 